\title{
AR ANTIBIOTISKĀM VIELĀM IMPREGNĒTU KOMPOZĪTMATERIĀLU ANTIBAKTERIĀLĀ DARBĪBA IN VITRO UN IN VIVO
}

Promocijas darba kopsavilkums medicinas doktora zinātniskā grāda iegūšanai Specialitāte - mikrobioloǵija 


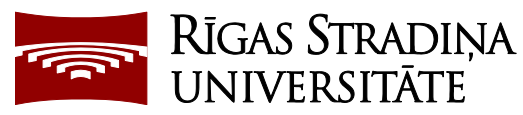

Ingus Skadiṇš

\title{
AR ANTIBIOTISKĀM VIELĀM \\ IMPREGNĒTU KOMPOZĪTMATERIĀLU \\ ANTIBAKTERIĀLĀ DARBĪBA \\ IN VITRO UN IN VIVO
}

\author{
Promocijas darba kopsavilkums \\ medicīnas doktora zinātniskā grāda iegūšanai
}

Specialitāte - mikrobioloǵija

Rīga, 2016 
Promocijas darbs izstrādāts Rīgas Stradiṇa universitātē (RSU) Bioloǵijas un mikrobiologijas katedrā.

Darba zinātniskās vadītājas:

Dr. med. profesore Juta Kroiča,

RSU Biologijas un mikrobiologijas katedra, Latvija

Dr. med. docente Ilze Šalma,

RSU Sejas žokḷu ķirurǵijas katedra, Latvija

Oficiālie recenzenti:

Dr. habil. med. profesors Jānis Vētra,

Rīgas Stradiṇa universitāte, Latvija

Dr. habil. biol. profesors Aleksandrs Rapoports,

Latvijas Universitāte

Dr. habil. sc. eng. profesors Gundars Mežinskis,

Rīgas Tehniskā universitāte, Latvija

Promocijas darba aizstāvēšana notiks 2016. gada 7. novembrī plkst. 15.00 Rīgas Stradina universitātes Medicīnas promocijas padomes atklātā sēdē Rīgā, Dzirciema ielā 16, Hipokrāta auditorijā.

Ar promocijas darbu var iepazīties RSU bibliotēkā un RSU mājas lapā: www.rsu.lv

Promocijas padomes sekretārs:

Dr. med. profesors Andris Jumtiņ̌s 


\section{SATURS}

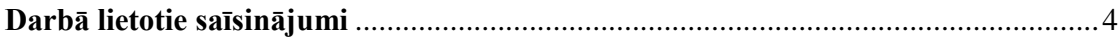

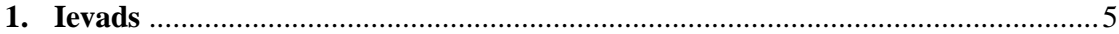

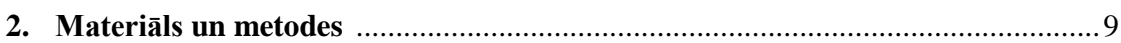

2.1. Biomateriālu paraugi............................................................................ 9

2.1.1. HAp/PLLA+cipro un HAp/PLLA+genta ......................................... 9

2.1.2. CDHAp/PCL+cipro, CDHAp/PCL+genta, CDHAp/PLLA+ cipro un CDHAp/PLLA+genta .................................................. 10

2.2. Antibakteriālo īpašību noteikšana in vitro....................................................... 11

2.2.1. Antibakteriālo īpašību noteikšana baktēriju suspensijā .................... 11

2.2.2. Antibakteriālo īpašību noteikšana ar disku difūzijas metodi............... 12

2.3. Izmeklējamās baktēriju kultūras un to jutība pret gentamicīnu un

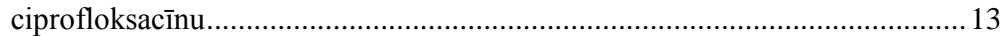

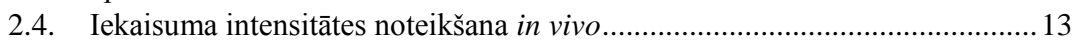

2.4.1. Eksperimentā izmantotie dzīvnieki............................................. 13

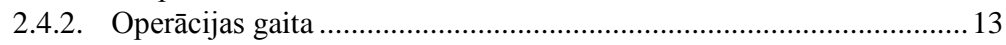

2.4.3. Izmeklējamais materiāls ........................................................ 15

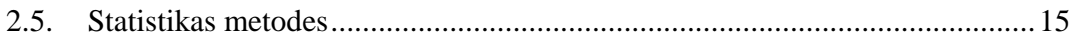

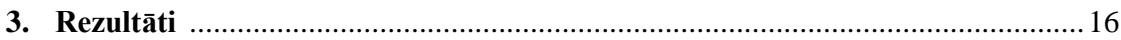

3.1. Antibiotisko vielu minimāli inhibējošā koncentrācija................................. 16

3.2. HAp/PLLA+genta un HAp/PLLA+cipro antibakteriālā efektivitāte in vitro ............................................................................... 16

3.3. CDHAp/PLLA+genta un CDHAp/PLLA+cipro antibakteriālā efektivitāte in vitro

3.4. CDHAp/PCL+genta un CDHAp/PCL+cipro antibakteriālā efektivitāte in vitro ..................................................................................... 24

3.5. IL-10 intensitāte in vivo ......................................................................... 27

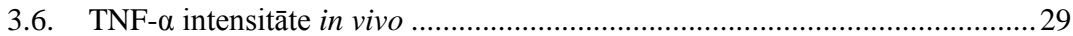

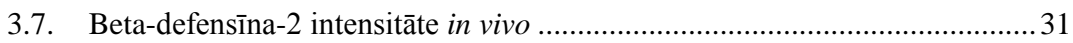

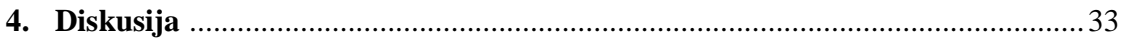

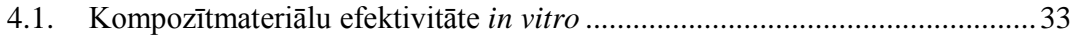

4.2. Iekaisuma citokīnu ekspresija in vivo...................................................... 44

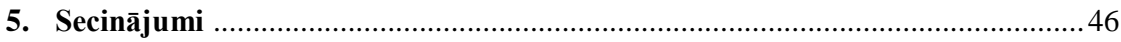

6. Publikācijas un prezentācijas par pētījuma tēmu ........................................ 47

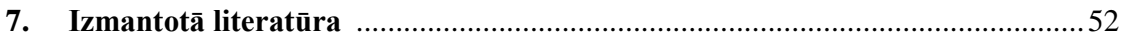




\section{DARBĀ LIETOTIE SAĪSINĀJUMI}

\begin{tabular}{|c|c|c|}
\hline Saīsinājums & $\begin{array}{c}\text { Nosaukums angḷu } \\
\text { valodā }\end{array}$ & Nosaukums latviešu valodā \\
\hline BAI & $\begin{array}{l}\text { biomaterial associated } \\
\text { infections }\end{array}$ & $\begin{array}{l}\text { biomateriālu saistîtās } \\
\text { infekcijas }\end{array}$ \\
\hline $\mathrm{CD}$ & calcium deficient & kalcija deficīts \\
\hline Cipro & ciprofloxacin & ciprofloksacīns \\
\hline ELISA & $\begin{array}{l}\text { enzyme-linked } \\
\text { immunosorbent assay }\end{array}$ & $\begin{array}{l}\text { enzīmu saistošā } \\
\text { imūnabsorbcijas metode }\end{array}$ \\
\hline Genta & gentamicin & gentamicīns \\
\hline HAp & hydroxyapatite & hidroksiapatīts \\
\hline MRSA & $\begin{array}{l}\text { methicillin-resistant } \\
\text { Staphylococcus aureus }\end{array}$ & $\begin{array}{l}\text { meticilīnrezistentais } \\
\text { Staphylococcus aureus }\end{array}$ \\
\hline MIC & $\begin{array}{l}\text { minimum inhibitory } \\
\text { concentration }\end{array}$ & $\begin{array}{l}\text { minimāli inhibējošā } \\
\text { koncentrācija }\end{array}$ \\
\hline PBS & $\begin{array}{l}\text { phosphate-buffered } \\
\text { saline }\end{array}$ & fosfāta buferšks̄īdums \\
\hline PCL & polycaprolactone & polikaprolaktons \\
\hline PLGA & $\begin{array}{l}\text { poly(lactic-co-glycolic } \\
\text { acid) }\end{array}$ & polipien-ko-glikolskābe \\
\hline PLLA & polylactic acid & polipienskābe \\
\hline SEM & $\begin{array}{l}\text { canning electron } \\
\text { microscope }\end{array}$ & $\begin{array}{l}\text { skenējošā } \\
\text { elektronmikroskopija }\end{array}$ \\
\hline TCP & tricalcium phosphate & trikalcija fosfăts \\
\hline TNF- $\alpha$ & tumor necrosis factor & tumora nekrozes faktors \\
\hline TSA & trypticase soy agar & triptikāzes sojas agars \\
\hline TSB & trypticase soy broth & triptikāzes sojas buljons \\
\hline UV & ultraviolet & ultravioletais starojums \\
\hline
\end{tabular}




\section{IEVADS}

Biomateriāli tiek izmantoti visās medicīnas nozarēs, lai aizvietotu cilvēka orgānus vai orgānu dạ̧as, tādējādi uzlabojot pacientu dz̄ives kvalitāti un paildzinot dzīvildzi. Ortopēdijā biomateriālus izmanto, lai aizvietotu locītavas vai kaulus un to daļas, stomatologijāa - kā zobu implantus, kardioloǵijā - kā mākslīgos sirds vārstuḷus vai kardiostimulatorus. Visās medicīnas nozarēs ḷoti plaši tiek izmantoti tādi biomedicīniskie implantāti kā intravenozie katetri, urīnpūšḷa katetri, intubācijas aprīkojums un citi biomateriālu veidotie medicīniskie aprīkojumi. Šo uzskaiti var turpināt ilgi un plaši, kas tikai apstiprina biomateriālu būtisko nozīmi mūsdienās (Huebsch et al., 2009).

Ar biomateriālu izmantošanu diemžēl samērā bieži ir saistītas dažādas komplikācijas, un viena no tām ir bakteriāli ierosinātas BAI. Lai gan pirms un pēc biomateriālu implantācijas operācijām tiek veikti profilakses pasākumi, nodrošinot operāciju sterilitāti, kā arī citi profilaktiski pasākumi, lai samazinātu BAI risku un infekcijas attīstības plašumu. Kaut arī ortopēdisko implantātu infekciju attīstības risks ir tikai 1-3\%, šo infekciju rezultātā pacientu letalitātes risks ir augsts (Darouiche et al., 2001), kā arī palielinās kopējās ārstniecības izmaksas, kas saistīts ar ortopēdiskā implantāta aizvietošanu un ilgāku hospitalizācijas laiku (Haenle et al., 2012).

BAI ir lokāla infekcija, kas var rasties pēc bakteriālas kontaminācijas operācijas laikā, pēcoperācijas periodā vai hematogēnas diseminācijas veidā no kāda cita cilvēka organisma infekcijas perēkḷa. N̦emot vērā lokālās infekcijas īpatnības, efektīvākā BAI profilakse ir ar antibiotiskajām vielām apstrādātu biomateriālu lietošana, lai mazinātu bakteriālo adhēziju pie biomateriāliem un biofilmu veidošanos (van de Belt et al., 2001).

Lai mazinātu BAI infekcijas risku, lokālai antibiotisko vielu izdalei no biomateriāla ir virkne priekšrocību, salīdzinot ar sistēmisku antibiotisko vielu lietošanu. Lokālā antibiotisko vielu izdale no biomateriāla l̦auj samazināt 
blakusparādību rašanās risku, kas rodas, sistēmiski lietojot antibiotiskās vielas (Campoccia et al., 2010). Biežākās no šīm blakusparādībām ir alerğiskas reakcijas, toksicitāte un disbakteriozes.

Lietojot kompozītmateriālus ar antibiotiskajām vielām un to savienojumu ar bionoārdāmu polimēru, tiek panākta antibiotisko vielu vadāma, kontrolēta un ilglaicīga izdale, kas paildzina biomateriāla antibakteriālās īpašības (Leprêtre et al., 2009).

Biomateriāla virsmai jāspēj ne tikai samazināt BAI risku, bet tai ir jābūt arī biosaderīgai ar apkārtējiem cilvēka audiem. To gan nosaka biomateriāla izmantošanas mērķis, jo neatkarīgi no biomateriāla sintēzes veida un pielietojuma tas tomēr cilvēka organismam ir svešksermenis (Franz et al., 2011).

\section{Darba mērķis}

In vitro un in vivo pētījumā noskaidrot, kāda kompozītmateriāliem ar antibiotiskajām vielām un ar biodegradējamu polimēru ir antibakteriālā efektivitāte pret biežākajiem pēcoperācijas infekciju ierosinātājiem $P$. aeruginosa un S. epidermidis.

\section{Darba hipotēzes}

1) Kompozītmateriāli ar biodegradējamu polimēru un antibiotiskajām vielām var būtiski samazināt pēcoperācijas infekcijas risku pēc implantātu izmantošanas.

2) Kompozītmateriāli ar biodegradējamu polimēru un antibiotiskām vielām var būtiskāk ietekmēt antibakteriālās īpašības, salīdzinot ar tādiem pašiem biomateriāliem bez polimēra pārklājuma. 
3) PLLA un PCL atšķirīgi ietekmē kompozītmateriālu ar biodegradējamu polimēru un antibiotiskajām vielām antibakteriālo efektivitāti pret $S$. epidermidis un $P$. aeruginosa.

4) Iekaisuma citokīnu un antibakteriālo peptīdu ekspresija audos ap biomateriālu ir intensīvāka, implantējot antibiotiskās vielas nesaturošu biomateriālu.

\section{Darba uzdevumi}

1) Izvērtēt dažādu kompozītmateriālu antibakteriālo efektivitāti pret $P$. aeruginosa un $S$. epidermidis in vitro.

2) Pētīt, kā biodegradējamais polimērs ietekmē biomateriālu antibakteriālo efektivitāti in vitro.

3) Salīdzināt PCL un PLLA ietekmi uz biomateriālu antibakteriālās darbības laiku.

4) Noteikt kompozītmateriālu ietekmi uz iekaisuma citokīna IL-10 un TNF- $\alpha$ un antibakteriālā peptīda $\beta$-defensīna-2 ekspresiju in vivo.

5) Izvērtēt kompozītmateriālu porainības līmeņa ietekmi uz biomateriālu antibakteriālās darbības laiku.

\section{Darba novitāte}

Darbā pētītie biomateriāli ir Latvijā oriğināli sintezēti pēc jaunākajām un līdz šim neizmantotām metodēm. Pirmo reizi tiek detalizēti pētīta šāda veida biomateriālu antibakteriālā darbība in vitro un to biosaderība in vivo, nosakot iekaisuma citokīnus un antibakteriālos peptīdus. Biosaderība pētīta, izmantojot ELISA metodi. Metode iekaisuma procesa izvērtēšanai apkārtējos audos tieši pēc biomateriāla implantācijas Latvijā tiek izmantota pirmo reizi. 


\section{Materiāli tehniskais nodrošinājums}

Rīgas Stradiņa universitātes Bioloǵijas un mikrobiologijas katedra nodrošināja pētījuma in vitro realizāciju, kā arī ELISA komplektus pētījumam in vivo. Pētîjums in vivo tika veikts Rīgas Stradinna universitātes eksperimenta dzīvnieku audzētavā. Pētītie biomateriāli tika oriğināli sintezēti Rīgas Tehniskās universitātes Rūdolfa Cimdina Rịgas biomateriālu inovāciju un attīstības centrā.

\section{Darba ētiskie aspekti}

Pētījumam in vivo tika saṇemta ațauja no Valsts Pārtikas un veterinārā dienesta, atļaujas Nr. 24 (sk. pielikumā).

\section{Personīgais ieguldījums}

Autors pats ir veicis visus in vitro un in vivo pētījumus, patstāvīgi veicis ķirurgisiskās operācijas eksperimentālajiem dzīvniekiem, audu paraugu savākšanu un izmeklēšanu, izmantojot molekulārās diagnostikas metodes.

\section{Darba struktūra}

Zinātniskais darbs uzrakstīts uz 106 lapaspusēm, ietver šādas nodaḷas: ievads, literatūras apskats, materiāls un metodes, rezultāti, diskusija, secinājumi, literatūras saraksts, pielikumi. Darbā iekḷautas 9 tabulas un 69 attēli. Izmantoti 210 literatūras avoti. 


\section{MATERIĀLS UN METODES}

\subsection{Biomateriālu paraugi}

\subsubsection{HAp/PLLA+cipro un HAp/PLLA+genta}

Hidroksiapatīta pulveris tika sagatavots ar slapjās ķīmiskās nogulsnēšanas metodi no kalcija oksīda (Sigma-Aldrich, $U K, \geq 97 \%$ ) un ortofosforskābes (Sigma-Aldrich, UK) šķīduma (Sokolova et al., 2014). Iegūtie jaunsintezētie pulveri tika sapresēti tabletēs $(\mathrm{d}=10, \mathrm{H}=3 \mathrm{~mm})$. Visi paraugi tika termiski apstrādāti $1100{ }^{\circ} \mathrm{C}$ temperatūrā 1 stundu ilgi. Pirms HAp paraugu piesūci-nāšanas ar antibiotiskajām vielām gentamicīns (koncentrācija 40 $\mathrm{mg} / \mathrm{ml}$ ) vai ciprofloksacīns (koncetrācija $100 \mathrm{mg} / 10 \mathrm{ml}$ ) tika izšḳīdināts dejonizētā ūden̄i. HAp paraugi tika piesūcināti ar ūdens-zāļu šķīdumu istabas temperatūrā atmosfēras spiedienā, pēc tam žāvēti $37{ }^{\circ} \mathrm{C}$ temperatūrā. Daļa no sagatavo-tajiem paraugiem tika izmantoti pārklāšanai ar PLLA. PLLA pārklājums HAp paraugiem tika pagatavots no $10 \mathrm{wt} \%$ poli(L-pienskābes) (Nature Works LLC, Mw = $110 \mathrm{kDa}$ ) šķīduma ar dihlormetānu (DCM) (SigmaAldrich, $U K)$. PLLA tika izšksīdināts DCM šķīdumā, to maisot 2 stundas istabas temperatūrā. Polimēra šķīdums tika infiltrēts HAp biokeramikas paraugos, izmantojot vakuuma impregnēšanas metodi 500 mbar spiedienā 15 minūtes. Pārklātie paraugi tika žāvēti istabas temperatūrā 24 stundas ilgi.

Atvērtā un kopējā porainība tika noteikta ar Arhimēda metodi, kas balstīta uz to, ka pielietotais spēks ir vienāds ar pārvietotā šḳīduma masu (Locs et al., 2013). Atvērtās porainības līmenis ir 34\%, bet kopējā porainība - 36\%. Ar SEM izmeklējot pārklāto paraugu šķērsgriezumu, bija redzams, ka HAp/PLLA paraugi, kas pārklāti ar $10 \mathrm{wt} \%$ PLLA, ir poraina mikrostruktūra ar poru izmēru diapazonu no 200 līdz 500 nm (1.1. attēls, kreisā puse). Tika iegūti paraugi ar PLLA pārklājumu, kas ir 2-5 $\mu \mathrm{m}$ biezi (1.1. attēls, labā puse). Lai 
izvērtētu, vai PLLA piemīt antibakteriālas īpašības, tika pagatavoti HAp/PLLA paraugi bez antibiotiskajām vielām.

Pēc šādas pašas metodikas tika pagatavoti $\downarrow$ HAp/PLLA+cipro, $\downarrow$ HAp+cipro un $\downarrow$ HAp/PLLA paraugi $(\downarrow-$ turpmāk darbā apzīmē kompozītmateriālus ar samazinātu porainības līmeni), kuriem atvērtā un kopējā porainība ir zemāka, respektīvi, 15\% - atvērtā porain̄iba un 19\% - kopējā porainība. Paraugi sintezēti, lai noskaidrotu, kā porainības līmenis ietekmē antibakteriālās darbības laiku. Katrai kompozītmateriālu grupai pret abu baktēriju kultūrām tika izgatavoti 8 paralēlie sērijas paraugi.
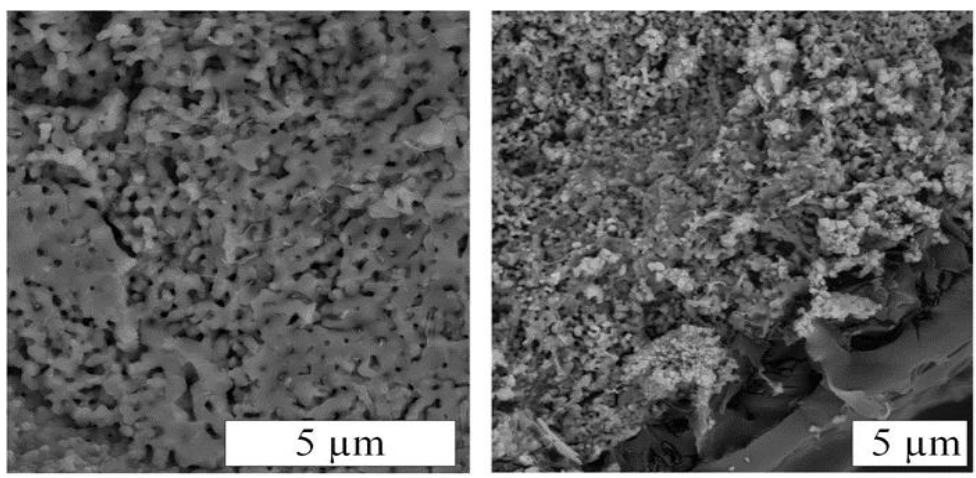

\section{2. attēls. HAp/PLLA šķērsgriezums (SEM)}

\subsubsection{CDHAp/PCL+cipro, CDHAp/PCL+genta, CDHAp/PLLA+cipro un CDHAp/PLLA+genta}

Kalcija deficīta hidroksiapatīta pulveri ieguva, izmantojot slapjās ķ̄imiskās nogulsnēšanas metodi. Tika izmantoti šādi reaǵenti: kalcija oksīds, iegūts no marmora (Sigma-Aldrich, UK, $\geq 97 \%$, ortofosforskābe (SigmaAldrich, $U K, \geq 85 \%$ un dejonizēts ūdens. Kompozīta veidošanas procesā tika izvērtēti vairāki faktori, piemēram, $\mathrm{pH}$, suspensijas temperatūra un skābe (Sokolova et al., 2014). 
PCL un CDHAp kompozīti ar biopolimēra sastāvu 20 wt\% un PLLA un CDHAp kompozīti ar biopolimēra sastāvu 30 wt\% tika sintezēti, izmantojot jaunu šķidro/cieto suspensiju tehnologiiju.

Gentamicīns 40 mg/ml koncentrācijāă, bet ciprofloksacīns 100 mg/10 ml koncentrācijā tika izšks̄īdināts dejonizētā ūdenī. Iegūtos šķīdumus sajauca ar dažādiem CDHAp/PCL un CDHAp/PLLA pulveriem. Iegūtos pulvera maisījumus žāvēja istabas temperatūrā 24 stundas. Izžāvētie kompozīti tika sapresēti tabletēs $(\mathrm{d}=12,5 \mathrm{~mm}, \mathrm{H}=$ 2,2 mm). CDHAp/PCL un CDHAp/PLLA tablešu porainību noteica ar ǵeometrisko metodi.

Lai izvērtētu, vai PLLA un PCL piemīt antibakteriālas īpašības, tika pagatavoti CDHAp/PCL un CDHAp/PLLA paraugi bez antibiotiskām vielām. Katrai kompozītmateriālu grupai pret abu baktēriju kultūrām tika izgatavoti 8 paralēlie sērijas paraugi. Kompozītmateriālos ar antibiotiskajām vielām vidējais antibiotisko vielu daudzums sasniedza $30 \mathrm{mg}$ uz 0,5 g parauga. Paraugu vidējā masa bija $0,4 \mathrm{~g}$.

Kalcija deficīta kompozītmateriāli pētījumā tika iekḷauti, balstoties uz to, ka HAp/PLLA kompozītmateriāliem piemīt vājas kaulaudu atjaunošanas spējas, jo šūnas, kuras ir atbildīgas par kaulaudu atjaunošanos, nevar piesaistīties pie biomateriāla līdz PLLA pilnīgai biodegradācijai (Armentano et al., 2010).

\subsection{Antibakteriālo īpašību noteikšana in vitro}

\subsubsection{Antibakteriālo īpašību noteikšana baktēriju suspensijāā}

Baktēriju suspensija tika pagatavota sterilos apstākḷos no $1 \mathrm{ml}$ TSB (Oxoid, UK) un $1 \mathrm{ml}$ baktēriju ar optisko blīvumu 0,5 pēc Makfārlenda (McFarland) standarta. Pirms biomateriālu paraugu ievietošanas baktēriju suspensijā tie visi - katrs atsevišķi - tika ievietoti $1 \mathrm{ml}$ truša plazmas $(B B L$, USA) un inkubēti termostatā (Memmert, Vācija) $37{ }^{\circ} \mathrm{C}$ temperatūrā un $100 \%$ 
relatīvā mitrumā - divas stundas. Pēc divām stundām biomateriāla paraugi ar sterilas pincetes palīdzību tika pārvietoti uz mēǵeni ar baktēriju suspensiju un $24 \mathrm{~h}$ inkubēti $37^{\circ} \mathrm{C}$. Baktēriju suspensija bez biomateriāla tika izmantota kā kontrole, lai salīdzinātu biomateriālu antibakteriālās īpašības, un arī 24 h tika inkubēta $37^{\circ} \mathrm{C}$.

Pēc $24 \mathrm{~h}$ inkubācijas $0,1 \mathrm{ml}$ baktēriju suspensijas tika uzsēta uz TSA (Oxoid, $U K)$, lai izvērtētu pētāmo biomateriālu antibakteriālās īpašības un efektivitāti. Tajā pašā laikā tika pagatavota jauna baktēriju suspensija un ar sterilas pincetes palīdzību pētāmo grupu biomateriāli tika pārvietoti jaunā TSB un baktēriju kultūru suspensijā uz nākamajām 24 h. Darbības tika atkārtotas katras 24 h, līdz izmeklējamo biomateriālu grupās divas dienas pēc kārtas vairs netika novērotas antibakteriālas īpašības, koloniju skaits uz TSA bija vienāds ar kontroles grupas koloniju skaitu uz TSA.

\subsubsection{Antibakteriālo īpašību noteikšana ar disku difūzijas metodi}

Kirby-Bauer disku difūzijas metode ir standartizēta metode, ko izmanto mikrobioloǵiskajās laboratorijās, lai noteiktu baktēriju jutību pret antibiotiskajām vielām (Bauer et al., 1966). Atbilstoši EUCAST (EUCAST, 2015) standartiem tika pagatavota baktēriju suspensija ar optisko blīvumu 0,5 pēc Makfarlenda standarta ar Makfarlenda optisko densitometru (Biosan, Latvija). Pagatavotā baktēriju suspensija ar sterilu vates kociṇu tika uzsēta uz sterilas TSA (Oxoid, $U K$ ) plates. Pēc baktēriju inokulācijas ar sterilu pinceti uz TSA tika novietoti biomateriālu diski un TSA barotne $24 \mathrm{~h}$ tika inkubēta termostatā $37{ }^{\circ} \mathrm{C}$ temperatūrā. Pēc $24 \mathrm{~h}$ tika analizētas biomateriālu paraugu antibakteriālās īpašības, izmērot sterilo zonu (diametru) ap biomateriālu diskiem. Pēc mērījumiem tika pagatavota jauna baktēriju suspensija, ko uzsēja uz jaunas, sterilas TSA barotnes, biomateriālu diskus pārnesa no vecās TSA barotnes uz jauno TSA barotni, un jauno barotni inkubēja vēl 24 h $37^{\circ} \mathrm{C}$. Darbības tika 
atkārtotas ik pēc 24 h, līdz izmeklējamo biomateriālu grupās divas dienas pēc kārtas netika novērotas antibakteriālas īpašības jeb sterila zona ap biomateriālu paraugiem.

\subsection{Izmeklējamās baktēriju kultūras un to jutība pret gentamicīnu un ciprofloksacīnu}

Visu biomateriālu antibakteriālās īpašības tika pētītas, izmantojot

S. epidermidis (ATCC 12228) un P. aeruginosa (ATCC 27853) baktēriju references kultūras. Lai noteiktu baktēriju jutību pret antibiotiskajām vielām, tika izmantota antibiotisko stripu ražotāju ieteiktā procedūra. Uz MilleraHintona (Mueller-Hinton) agara (Oxoid, UK) ar sterilu vates kociņu tika uzsētas baktērijas pēc 0,5 Makfarlenda standarta pagatavotas suspensijas. Pēc tam tika uzlikts gentamicīna vai ciprofloksacīna antibiotiskais strips (Liofilchem, Itâlija). Agara plates inkubēja $37{ }^{\circ} \mathrm{C}$ temperatūrā. Rezultātus izvērtēja pēc $24 \mathrm{~h}$ inkubācijas.

\subsection{Iekaisuma intensitātes noteikšana in vivo}

\subsubsection{Eksperimentā izmantotie dzīvnieki}

Lai noteiktu iekaisuma citokīnu intensitāti audos ap implantēto biomateriālu, eksperimentā tika izmantoti trīs mēnešus veci trušu tēviņi. Visi izmantotie truši bija $3 \mathrm{~kg}$ smagi. Eksperimenta sākumā un gaitā neviens no trušiem neslimoja, tika ievēroti visi ētiskie aspekti un saņemta aţ̦auja no Valsts Pārtikas un veterinārā dienesta

\subsubsection{Operācijas gaita}

Pirms operācijas tika pagatavotas $P$. aeruginosa un $S$. epidermidis baktēriju suspensijas ar optisko blīvumu 0,5 pēc Makfarlenda standarta. Trusim skausta rajonā tika noskūts apmatojums un veikta ādas apstrāde ar joda škīdumu. Noskūtajā un ar antiseptiskajiem līdzekḷiem apstrādātajā skausta 
rajonā veica lokālu atsāpināšanu ar 2\% lidokaīna hidrohlorīda šķīdumu. Sterilos apstākḷıs, ar sterilu skalpeli veica ādas incīzija, izveidojot 2,5 cm lielu brūci. Pakāpeniski ar skalpel̦a palīdzību izveidoja pietiekami lielu zemādas kabatu, kurā varētu implantēt biomateriāla tableti. Pēc biomateriāla ievietošanas zemādas kabatā brūce tika inficēta ar $0,1 \mathrm{ml}$ baktēriju suspensiju. Pēc brūces inficēšanas ar baktēriju suspensiju brūce tika aizšūta ar steriliem diegiem. Tika uzliktas 3 līdz 4 šuves, cieši noslēdzot brūci. Pēcoperācijas periods pagāja bez komplikācijām, eksperimenta laikā neviens trusis neslimoja un neaizgāja bojā. Biomateriālu paraugi tika izṇemti pēc 4 nedẹlāam, kas ir vislabākais laiks iekaisuma zonas izvērtēšanai ap biomateriālu un distancēti no tā, jo ilgākā laika periodā iekaisuma process var izsīkt. Savukārt par 4 nedēḷām īsākā laika periodā ir grūti izvērtēt, vai iekaisuma reakcija ir no biomateriāla kontaminācijas vai tā ir normāla organisma imūnā atbilde uz ķirurğisko iejaukšanos.

Tika implantēti HAp/PLLA+cipro, HAp+cipro, HAp/PLLA, HAp/ PLLA+genta un HAp+genta, kas bija inficēti ar $P$. aeruginosa vai S. epidermidis (1.1. tabula).

1.1. tabula

In vivo pētījumā izmantoto paraugu grupas

\begin{tabular}{|l|l|l|l|l|l|l|}
\hline $\begin{array}{l}\text { Paraugu } \\
\text { grupa }\end{array}$ & $\mathrm{HAp}$ & $\mathrm{PLLA}$ & cipro & genta & $\begin{array}{l}\text { P. } \\
\text { aeruginosa }\end{array}$ & S. epidermidis \\
\hline A grupa & $\mathrm{X}$ & $\mathrm{X}$ & $\mathrm{X}$ & & $\mathrm{X}$ & \\
\hline B grupa & $\mathrm{X}$ & $\mathrm{X}$ & $\mathrm{X}$ & & & $\mathrm{X}$ \\
\hline C grupa & $\mathrm{X}$ & $\mathrm{X}$ & & $\mathrm{X}$ & $\mathrm{X}$ & \\
\hline D grupa & $\mathrm{X}$ & $\mathrm{X}$ & & $\mathrm{X}$ & & $\mathrm{X}$ \\
\hline E grupa & $\mathrm{X}$ & & $\mathrm{X}$ & & $\mathrm{X}$ & \\
\hline F grupa & $\mathrm{X}$ & & $\mathrm{X}$ & & & $\mathrm{X}$ \\
\hline G grupa & $\mathrm{X}$ & & & $\mathrm{X}$ & $\mathrm{X}$ & \\
\hline H grupa & $\mathrm{X}$ & & & $\mathrm{X}$ & & $\mathrm{X}$ \\
\hline I grupa & $\mathrm{X}$ & $\mathrm{X}$ & & & $\mathrm{X}$ & \\
\hline J grupa & $\mathrm{X}$ & $\mathrm{X}$ & & & & $\mathrm{X}$ \\
\hline
\end{tabular}




\subsubsection{Izmeklējamais materiāls}

Lai noteiktu IL-10, TNF- $\alpha$ un beta-defensīna-2 līmeni apkārtējos audos ap implantēto biomateriālu, tika izmantota standartizētā ELISA metode ar ELISA komplektiem (USCN life science un MyBioSource, USA). Četras nedēḷas pēc biomateriālu implantācijas truši tika eitanizēti. Ar sterilu skalpeli tika pārgriezta dzīvnieka āda implantētā biomateriāla vietā. Tika savākti vienāda lieluma audu paraugi: trīs audu paraugi no tieši piegulošiem audiem ap biomateriālu, trīs audu paraugi - no ārējās zonas ap biomateriālu un trīs audu paraugi - distancēti $(1,5 \mathrm{~cm})$ no implantētā biomateriāla vietas. Audus pirms homogenizācijas noskaloja ar aukstu PBS (0,01 mol/l, pH 7,0-7,2), lai noskalotu asiṇu atlikumus no audiem. Audi tika sagriezti smalkākos gabaliņos un homogenizēti. Iegūto audu suspensiju ievietoja ultraskaņas vannā, lai pārplēstu šūnu membrānas, pēc tam to centrifugēja 5 minūtes ar 5000 apgriezieniem minūtē. Pēc ELISA standartazētas procedūras 96 iedobīšu mikroplati analizēja ar ELISA lasītāju spektrofotometriski, viļ̣na garums $450 \mathrm{~nm} \pm 10 \mathrm{~nm}(T E C A N$, Šveice).

\subsection{Statistiskās metodes}

Iegūto rezultātu izvērtēšanai tika izvēlētas neparametriskās statistiskās metodes. Tika izmantots Manna-Vitnija tests (Mann et al., 1947), lai izvērtētu, vai ir statistiski ticamas atšķirības starp pētījumā izmantoto biomateriālu grupu antibakteriālo ilgumu. Par statistiski ticamu tika pieņemts, ja $p$ vērtība ir mazāka vai vienāda ar 0,05. Rezultāti tika ievadīti Microsoft Excel 2014, un statistiskā analīze tika veikta ar SPSS 22.0 (statistical package for the social sciences). 


\section{REZULTĀTI}

\subsection{Antibiotisko vielu minimāli inhibējošā koncentrācija}

Izmantojot standartizēto E-testu metodi, tika noskaidrots, ka pētījumā izmantotās kultūras $P$. aeruginosa un $S$. epidermidis ir jutīgas pret pētījumā izmantotajām antibiotiskajām vielām. Ciprofloksacīna MIC pret S. epidermidis ir $0,094 \mu \mathrm{g} / \mathrm{ml}$, pret $P$. aeruginosa $-0,125 \mu \mathrm{g} / \mathrm{ml}$. Savukārt gentamicīna MIC pret $S$. epidermidis ir $0,19 \mu \mathrm{g} / \mathrm{ml}$, pret $P$. aeruginosa $-1,0 \mu \mathrm{g} / \mathrm{ml}$.

\subsection{HAp/PLLA+genta un HAp/PLLA+cipro antibakteriālā efektivitāte in vitro}

Izmantojot antibakteriālo īpašību noteikšanas metodi baktēriju suspensijā, ir redzams, ka HAp/PLLA+genta biomateriālu maksimālais antibakteriālās darbības ilgums pret S. epidermidis ir 264 h, bet minimālais antibakteriālais ilgums - 216 h, tādējādi vidējais antibakteriālais ilgums pret S. epidermidis ir 249,6 6 16,78 h (2.1. attēls). HAp/PLLA biomateriālam antibakteriālās īpašīibas netika novērotas ne pret vienu no baktēriju kultūrām.

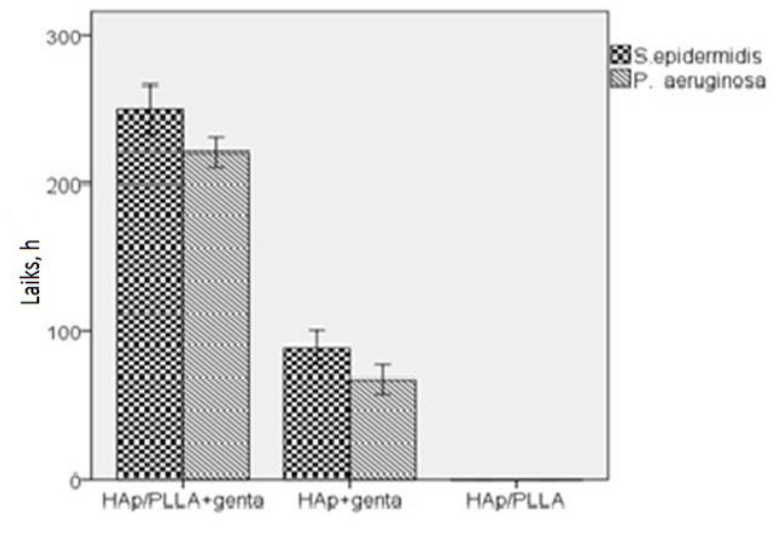

2.1.attēls. Vidējais antibakteriālais ilgums dažādiem kompozītmateriāliem ar gentamicīnu 
Biomateriāliem bez PLLA polimēra (HAp+genta) antibakteriālais ilgums ir ievērojami mazāks, to maksimālais antibakteriālais ilgums pret S. epidermidis ir $96 \mathrm{~h}$, bet minimālais antibakteriālais ilgums ir $72 \mathrm{~h}$, vidējais antibakteriālais ilgums ir 88,8 $\pm 11,59$ h. Izmantojot Manna-Vitnija testu, ir redzams, ka biomateriāliem ar PLLA un gentamicīnu ir statistiski ticami lielāks antibakteriālais ilgums pret $S$. epidermidis nekā biomateriāliem bez PLLA ( $\mathrm{p}<$ $0,001)$.

HAp/PLLA+genta un HAp+genta spēja inhibēt $S$. epidermidis augšanu in vitro kopumā ir atšķirīga, bet vienāda pirmajās trīs eksperimenta dienās, kad gandrīz visas $S$. epidermidis baktērijas tika inhibētas. Nākamajās eksperimenta dienās HAp/PLLA+genta saglabāja augstas S. epidermidis augšanas inhibīcijas spējas un zaudēja tās pakāpeniski, bet $\mathrm{HAp}+$ genta $S$. epidermidis augšanas inhibīcijas spējas zaudēja strauji.

Manna-Vitnija tests parādīja, ka starp HAp/PLLA+genta un HAp+genta biomateriālu grupām pret $P$. aeruginosa ir statistiski ticama atšķirība $(\mathrm{p}<0,001)$, un šo grupu maksimālais un vidējais antibakteriālais ilgums ir mazāks nekā pret S. epidermidis. Maksimālais HAp/PLLA+genta antibakteriālais ilgums pret $P$. aeruginosa ir $240 \mathrm{~h}$, bet minimālais antibakteriālais ilgums - 216 h, kas ir vienāds ar̄̄ pret S. epidermidis. HAp+genta maksimālais antibakteriālais ilgums pret $P$. aeruginosa ir $72 \mathrm{~h}$, minimālais antibakteriālais ilgums - $48 \mathrm{~h}$. Attiecīgi vidējais HAp/PLLA+genta antibakteriālais laiks pret P. aeruginosa ir 220,8 $\pm 10,11 \mathrm{~h}$, bet HAp+genta $-67,2 \pm 10,11 \mathrm{~h}$.

HAp+genta un HAp/PLLA+genta $P$. aeruginosa augšanas inhibīcijas dinamika pirmajās $48 \mathrm{~h}$ statistiski ticami neatšķiras $(\mathrm{p}>0,05)$, bet, sākot ar trešo eksperimenta dienu, novēroja statistiski ticamas atšķirīibas $(\mathrm{p}<0,001)$ starp HAp/PLLA+genta un HAp+genta biomateriāliem pret $P$. aeruginosa. Līdzīgi kā $S$. epidermidis gadījumā, HAp/PLLA+genta biomateriāliem pret P. aeruginosa novēroja pakāpenisku antibakteriālo īpašību zudumu. 
Līdzīgas tendences pret abām pētījumā izmantotajām baktēriju kultūrām ir gan HAp/PLLA+cipro un HAp+cipro biomateriāliem, gan HAp/PLLA+genta un HAp+genta gadījumā. HAp/PLLA+cipro maksimālais antibakteriālais laiks pret S. epidermidis bija 288 h, minimālais antibakteriālais laiks - 264 h. Savukārt HAp+cipro maksimālais un minimālais antibakteriālais laiks pret S. epidermidis bija līdzīgs kā HAp+genta un sasniedza attiecīgi 96 h un 72 h. Tādējādi vidējais antibakteriālais laiks biomateriāliem ar PLLA ir ilgāks nekā biomateriāliem bez PLLA (2.2. attēls).

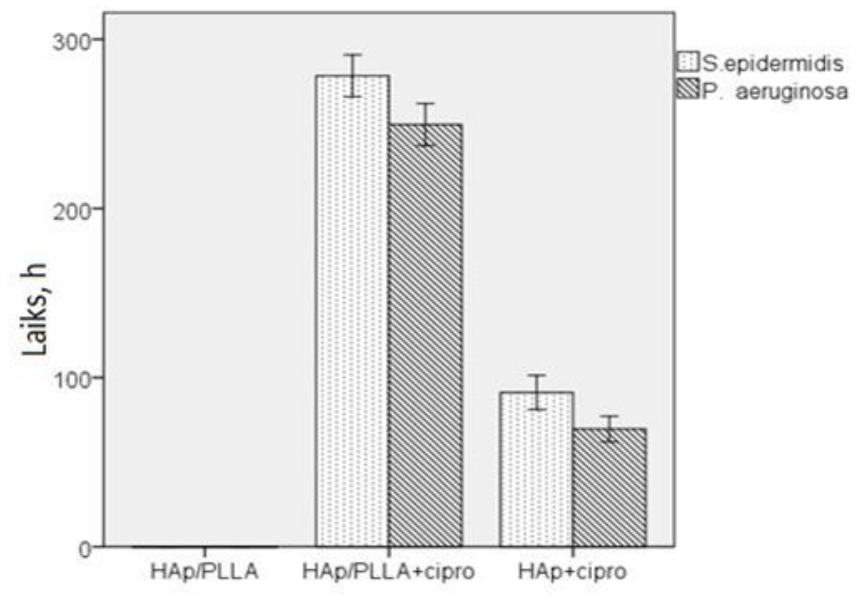

\section{2. attēls. Vidējais antibakteriālais laiks dažādiem kompozītmateriāliem ar ciprofloksacīnu}

Vidējais HAp/PLLA+cipro antibakteriālais laiks pret $P$. aeruginosa ir īsāks nekā pret $S$. epidermidis. Starp HAp/PLLA+cipro un HAp+cipro pret $P$. aeruginosa tika novērota statistiski ticama atšksirība $(\mathrm{p}<0,001)$.

HAp/PLLA+cipro un HAp+cipro pilnībā inhibē S. epidermidis augšanu, kas pirmajās trijās eksperimenta dienās statistiski ticami neatšķiras ( $\mathrm{p}>0,05)$, bet, sākot ar ceturto eksperimenta dienu - 96 stundu laika atzīmē, novēro 
statistiski ticamas $(\mathrm{p}<0,005)$ atšķirības. Savukārt $P$. areruginosa augšanas inhibīcijas dinamikā novēroja statistiski ticamas atšķirības $(p<0,05)$ jau eksperimenta $72 \mathrm{~h}$ atzīmē.

Izmantojot Manna-Vitnija testu, var secināt, ka biomateriāli HAp/PLLA+genta, HAp+genta, HAp/PLLA+cipro un HAp+cipro - nevienai no baktēriju kultūrām statistiski ticami nemaina $(\mathrm{p}>0,05)$ inhibēto baktēriju procentuālo daudzumu laika posmā no $24 \mathrm{~h} \mathrm{līdz} 48 \mathrm{~h}$.

Nosakot HAp/PLLA+cipro un HAp+cipro antibakteriālās īpašības pret abām baktēriju kultūrām ar disku difūzijas metodi , redzams, ka antibakteriālās izmeklēšanas metode neietekmē biomateriālu paraugu antibakteriālo laiku ne pret vienu no pētījumā izmantojamām baktēriju kultūrām. Tāpat neatšksiras arī S. epidermidis augšanas inhibīcija (3.7. attēls), jo HAp/PLLA+cipro savas antibakteriālās īpašības saglabā ilgu laika periodu un tās zaudē pakāpeniski, bet HAp+cipro savas antibakteriālās īpašības zaudē ḷoti strauji, un 5 dienu laikā tās līdzinās nullei. Izmantojot disku difūzijas metodi, redzams, ka HAp+cipro biomateriāli izdala lielāku antibiotisko vielu koncentrāciju nekā HAp/PLLA+cipro, jo pirmajās eksperimenta dienās ir novērojams lielāks sterilās zonas diametrs, kas liecina par lielāku antibiotisko vielu difundēšanu no biomateriāla parauga. HAp+cipro ar̄̄ pret $P$. aeruginosa izdala lielāku antibiotisko vielu daudzumu, jo sterilās zonas diametrs ir lielāks nekā HAp/PLLA+cipro.

Taču HAp/PLLA+cipro kopējais antibakteriālais laiks pret P. aeruginosa ir ilgāks nekā HAp+cipro, un tā antibakteriālās īpašības tika zaudētas pakāpeniski visa in vitro pētījuma laikā.

Biomateriāliem ar zemāku porainību - $\downarrow$ HAp/PLLA+cipro - statistiski ticami $(\mathrm{p}<0,001)$ atškiras antibakteriālais laiks, salīdzinot ar biomateriāliem, kuriem ir augstāka porainība, - Hap/PLLA+cipro. Statistiski ticamas atšķirības $(\mathrm{p}<0,001)$ novēroja arī dažāda porain̄ības līmeņa biomateriāliem bez PLLA ar antibiotiskām vielām (2.3. attēls). 


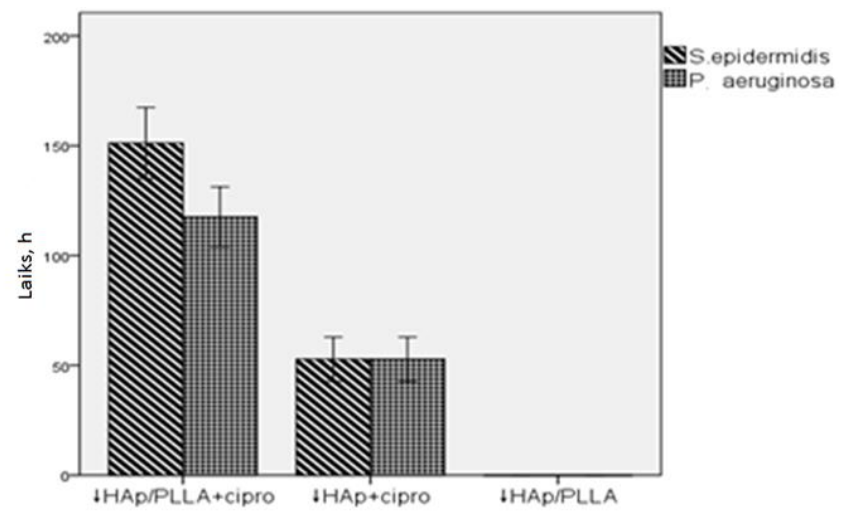

\section{3. attēls. Vidējais antibakteriālais laiks kompozītmateriāliem ar samazinātu porainību un ciprofloksacīnu}

$\downarrow$ HAp+cipro S. epidermidis augšanas inhibīcijas spējas ir mazākas nekā HAp+cipro biomateriāliem ar augstāku porainību, kas liecina, ka no porainības līmeņa ir atkarīga biomateriālu spēja inhibēt baktēriju augšanu. Biomateriāliem ar PLLA spēja inhibēt $S$. epidermidis augšanu arī ir atkarīga no porainības līmeņa, ņemot vērā, ka HAp/PLLA+cipro antibakteriālais laiks ir ilgāks nekā $\downarrow$ HAp/PLLA+cipro.

Porainības līmeņa ietekmi uz antibakteriālo laiku pierāda arī pētījums ar $P$. aeruginosa baktēriju kultūru, kurā redzams, ka zemākas porainības biomateriāliem piemīt īslaicīga $P$. aeruginosa augšanas inhibīcijas dinamika, salīdzinot ar augstākas porainības biomateriāliem.

Zemas porainības biomateriālu grupā statistiski ticamas inhibēto baktēriju procentuālās izmainas laikā no $24 \mathrm{~h}$ līdz $48 \mathrm{~h}$ tika novērotas $\downarrow$ HAp+cipro pret $S$. epidermidis kultūru (Manna-Vitnija tests, $\mathrm{p}<0,05$ ), tāpat arī statistiski ticami samazinājās pret $P$. aeruginosa kultūru $(\mathrm{p}<0,05)$.

Pirmajās 24h neatkarīgi no PLLA esamības zema porain̄ibas līmeņa biomateriāliem statistiski ticamas izmaiņas netika novērotas $(\mathrm{p}<0,05)$, bet izmaiņas sāka notikt in vitro pētījuma $48 \mathrm{~h}$ atskaites posmā un Manna-Vitnija 
tests norādīja, ka zema porainības līmeņa biomateriāliem bez PLLA inhibēto baktēriju procentuālās izmainas samazinājums $48 \mathrm{~h}$ ir statistiski ticami lielāks nekā zema porainības līmeņa biomateriāliem ar PLLA $(\mathrm{p}<0,05)$ neatkarīgi no baktēriju kultūras.

\subsection{CDHAp/PLLA+genta un CDHAp/PLLA+cipro antibakteriālā efektivitāte in vitro}

Izmantojot antibakteriālo īpašību noteikšanas metodi baktēriju suspensijā, tika noskaidrots, ka CDHAp/PLLA+genta maksimālais antibakteriālais laiks pret S. epidermidis ir 264 h, minimālais antibakteriālais laiks sasniedz 240 h, bet vidējais antibakteriālais laiks pret $S$. epidermidis ir 249,6 \pm 16,78 h (2.4. attēls).

CDHAp/PLLA biomateriālam pret $S$. epidermidis un $P$. aeruginosa antibakteriālās īpašības netika novērotas.

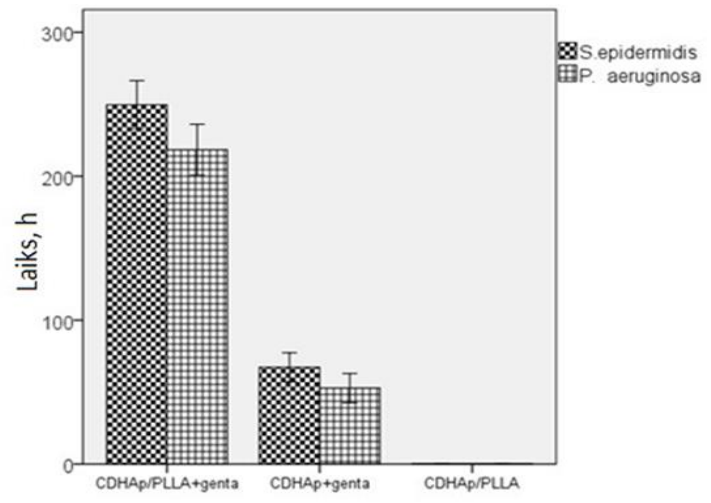

2.4. attēls. Vidējais antibakteriālais laiks kompozītmateriāliem ar kalcija deficītu un gentamicīnu

Ar Manna-Vitnija testu tika apstiprināts, ka CDHAp/PLLA+genta un CDHAp+genta antibakteriālie laiki pret $S$. epidermidis statistiski ticami ( $<<$ 
0,001) atšķiras. CDHAp/PLLA+genta pilnībā inhibēja S. epidermidis augšanu pêtījuma pirmajās 5 dienās un pēc tam šīs spējas zaudēja pakāpeniski, savukārt CDHAp+genta pilnībā inhibēja $S$. epidermidis augšanu tikai pirmajā pētījuma dienā, bet jau otrajā dienā novēroja strauju antibakteriālo īpašību zudumu.

CDHAp+genta maksimālais antibakteriālais laiks pret S. epidermidis bija ir $72 \mathrm{~h}$, un minimālais antibakteriālais laiks bija ir $48 \mathrm{~h}$, veidojot vidējo antibakteriālo laiku 67,2 \pm 10,11 h. CDHAp/PLLA+genta un CHAp+genta spēja inhibēt $P$. aeruginosa augšanu ir līdzīga kā pret $S$. epidermidis, tikai CDHAp/PLLA+genta kopējā $P$. aeruginosa augšanas inhibīcijas dinamikā uzrāda ātrāku antibakteriālo īpašību zaudēšanu kopumā, kā arī maksimālais un minimālais antibakteriālais laiks ir atšķirīgs, un sasniedz attiecīgi 240 h un $196 \mathrm{~h}$.

Statistiski ticamas izmaiņas no $24 \mathrm{~h}$ līdz $48 \mathrm{~h}$ tika novērotas CDHAp+genta pret $P$. aeruginosa baktēriju kultūru (Manna-Vitnija tests, $\mathrm{p}<0,05)$, tāpat kā statistiski ticami samazinājās pret $S$. epidermidis kultūru $(\mathrm{p}<0,05)$. Pārējiem CDHAp/PLLA+genta biomateriāliem statistiski ticamas izmaiņas netika novērotas (Manna-Vitnija tests, $\mathrm{p}>0,05$ ).

Šādas statistiski ticamas izmaiņas no $24 \mathrm{~h}$ līdz $48 \mathrm{~h}$ arī nenovēroja CDHAp/PLLA+cipro un CDHAp+cipro $(\mathrm{p}>0,05)$ pret $S$. epidermidis un $P$. aeruginosa. CDHAp+cipro statistiski ticamas izmaiņas $(\mathrm{p}<0,05)$ novēroja pret abām in vitro pētījumā izmantotajām baktēriju grupām laika atskaites posmos no $48 \mathrm{~h}$ līdz $72 \mathrm{~h}$, bet CDHAp/PLLA+cipro šādas statistiski ticamas izmaiņas minētajā laika posmā nenovēroja ne pret vienu no baktēriju kultūrām. CDHAp/PLLA+cipro novēroja $S$. epidermidis augšanas inhibīcijas spēju pakāpenisku zudumu, un, salīdzinot ar tās pašas grupas biomateriāliem bez PLLA (CDHAp+cipro), tā antibakteriālais laiks ir statistiski ticami $(\mathrm{p}<0,001)$ ilgāks pret $S$. epidermidis.

Ja salīdzina CDHAp/PLLA+cipro ar CDHAp/PLLA+genta antibakteriālo darbību pret S. epidermidis, tad var novērot, ka CDHAp/PLLA+cipro 
antibakteriālais laiks ir īsāks un sasniedz 213,6 $\pm 13,62 \mathrm{~h}$ (2.5. attēls). Maksimālais antibakteriālais laiks, ko spēja uzrādīt CDHAp/PLLA+cipro pret S. epidermidis, bija 240 h, minimālais - 192 h. CDHAp+cipro uzrādīja ilgāku antibakteriālo laiku pret S. epidermidis nekā CDHAp+genta, bet statistiski ticamas izmaiņas nenovēroja $(\mathrm{p}>0,05)$.

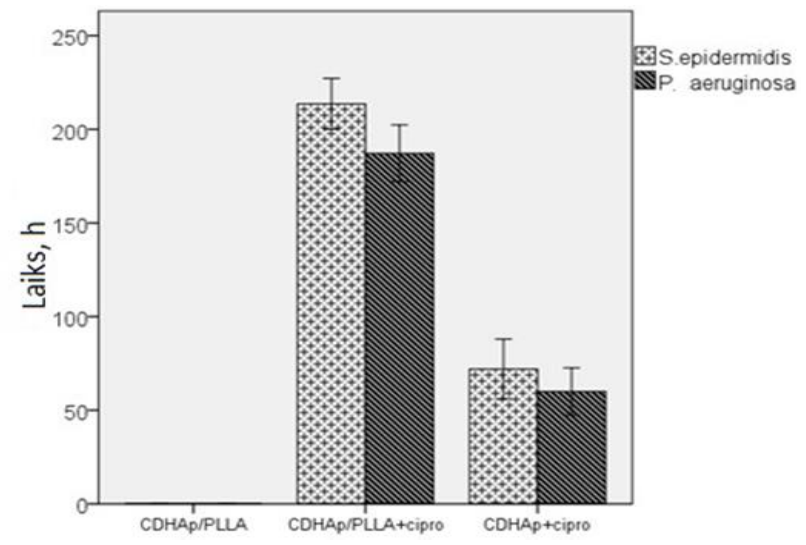

\section{5. attēls. Vidējais antibakteriālais laiks kompozītmateriāliem ar ciprofloksacīnu un PLLA}

CDHAp/PLLA+cipro un CDHAp+cipro saglabājas kompozītmateriāliem raksturīgas inhibīcijas spējas pret $P$. aeruginosa, jo CDHAp/ PLLA+cipro gadījumā novēroja ilgstošas spējas nomākt $P$. aeruginosa baktēriju augšanu, un šīs spējas zuda pakāpeniski. CDHAp+cipro izteiktas antibakteriālās spējas novēroja pirmajās pētījuma dienās. Tika novērotas raksturīgās straujās antibakteriālo īpašību kritumu ar strauju antibiotisko vielu izdali pirmajās pētījuma dienās.

CDHAp+cipro biomateriālā statistiski ticamas inhibēto baktēriju procentuālās izmaiņas (Manna-Vitnija tests, $\mathrm{p}<0,05$ ) novēroja pētījuma atskaites laika posmos no $48 \mathrm{~h}$ līdz $72 \mathrm{~h}$ pret $P$. aeruginosa. CDHAp+cipro maksimālais antibakteriālais laiks pret $P$. aeruginosa ir $72 \mathrm{~h}$ un minimālais 
antibakteriālais laiks ir 48 h. Savukārt CDHAp/PLLA+cipro maksimālais antibakteriālais laiks pret $P$. aeruginosa ir ievērojami ilgāks nekā CDHAp+cipro, un sasniedz 192 h, bet tas ir mazāks nekā pret S. epidermidis. Novēro statistiski ticamas atšķirības (Manna-Vitnija tests, $\mathrm{p}<0,001$ ) starp CDHAp/PLLA+cipro un CDHAp+cipro antibakteriālo laiku pret $P$. aeruginosa. Salīdzinot dažādu kompozītmateriālu antibakteriālās īpašības, redzams, $\mathrm{ka}$ ir statistiski ticamas (Manna-Vitnija tests, $\mathrm{p}<0,001$ ) atšķirīibas starp Hap/PLLA+cipro un CDHAp/PLLA+cipro pret abām baktēriju kultūrām (3.27. attēls un 3.28. attēls), savukārt tiem pašiem kompozītmateriāliem ar gentamicīnu nenovēru statistiski ticamas (Manna-Vitnija tests, $\mathrm{p}>0,05$ ) atšksirības pret abām baktēriju kultūrām.

\subsection{CDHAp/PCL+genta un CDHAp/PCL+cipro antibakteriālā efektivitāte in vitro}

Pētījuma ietvaros tika izpētîti arī kompozītmateriāli ar citu bionoārdošos polimēru PCL, kuri savienoti ar antibiotiskajām vielām. Izmantojot MannaVitnija testu, ir redzams, ka CDHAp/PCL+genta biomateriāliem ir statistiski ticami $(\mathrm{p}<0,001)$ atšķirīgs antibakteriālais laiks nekā CDHAp/PLLA+genta pret S. epidermidis. Statistiski ticami atšķiras $(\mathrm{p}<0,001)$ arī CDHAp/ PCL+genta antibakteriālais laiks, salīdzinot ar CDHAp+genta pret S. epidermidis. CDHAp/PCL+genta pētījumā parāda visilgāko antibakteriālo laiku (2.6. attēls) pret S. epidermidis, sasniedzot antibakteriālo ilgumu 319,2 \pm $16,19 \mathrm{~h}$. 


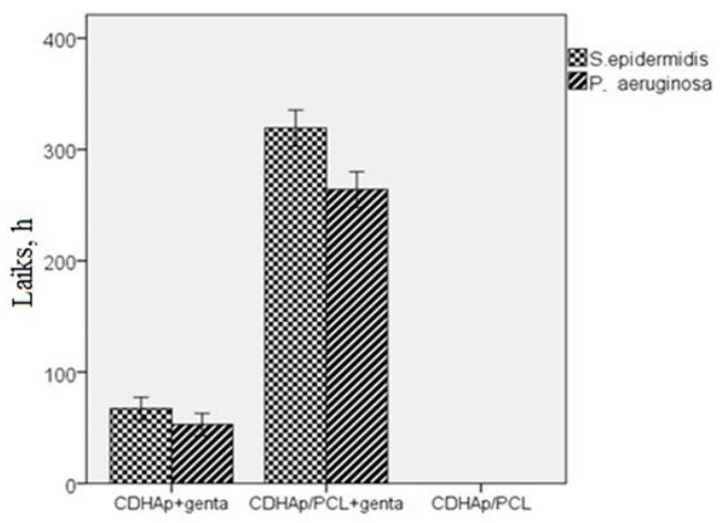

\section{6. attēls. Vidējais antibakteriālais laiks kompozītmateriāliem ar gentamicīnu un PCL}

Ilgais CDHAp/PCL+genta antibakteriālais laiks ir saistīts ar atsevišķu paraugu ilgo maksimālo antibakteriālo laiku pret S. epidermidis - 336 h, un minimālo antibakteriālo laiku -288 h. Pret $P$. aeruginosa CDHAp/PCL+genta maksimālais antibakteriālais laiks sasniedz 288 h, bet minimālais antibakteriālais laiks ir $240 \mathrm{~h}$.

CDHAp/PCL+genta CDHAp/PCL+genta spēja inhibēt $S$. epidermidis augšanu pilnībā saglabājas ilgu laiku no 192 h līdz 216 h, un arī vēlāk pilnībā S. epidermidis augšana netiek nomākta, antibakteriālās īpašības tiek zaudētas pakāpeniski. Biomateriālu paraugi bez PCL antibakteriālās spējas zaudē strauji, un in vitro pētījuma laika atzīmē no $24 \mathrm{~h}$ līdz $48 \mathrm{~h}$ novēro statistiski ticamas atšķirības inhibēto baktēriju procentuālajā rādītājā $(\mathrm{p}<0,05)$, izmantojot Manna-Vitnija testu.

Pilna $P$. aeruginosa augšanas inhibīcija CDHAp/PCL+genta tika novērota līdz pētījuma 168 stundu atzīmei. Pētījuma turpinājumā visiem kompozītmateriāliem ar antibiotiskajām vielām un bionoārdāmu polimēru novēroja kopēju tendenci, ka antibakteriālās spējas tiek zaudētas pakāpeniski. 
CDHAp/PCL+genta pret P.aeruginosa nenovēroja statiski ticamas ( $\mathrm{p}>0,05$ ) izmaiņas pētījuma laika posmā no $24 \mathrm{~h}$ līdz $48 \mathrm{~h}$ un arī pētījuma laika posmā no $48 \mathrm{~h}$ līdz $72 \mathrm{~h}$, bet CDHAp+genta novēro statistiski ticamas $(\mathrm{p}<0,05)$ izmainas gan pētījuma laika posmā no $24 \mathrm{~h} \mathrm{līdz} 48 \mathrm{~h}$, gan pētījuma laika posmā no $48 \mathrm{~h}$ līdz 72h.

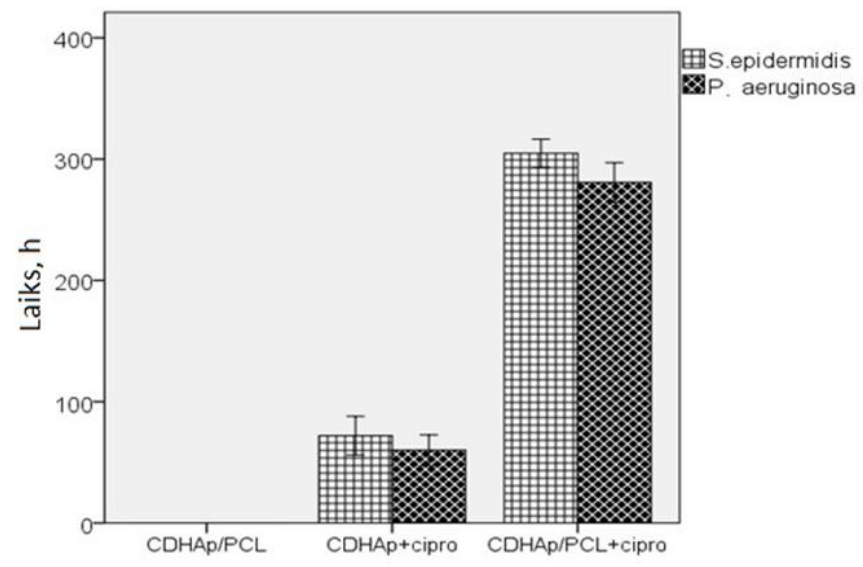

\section{7. attēls. Vidējais antibakteriālais kompozītmateriāliem ar ciprofloksacīnu un PCL}

Visilgāko antibakteriālo laiku pētījumā pret $P$. aeruginosa uzrāda CDHAp/PCL+cipro, sasniedzot 280,8 $\pm 16,19$ h. Maksimālais antibakteriālais laiks pret $P$. aeruginosa CDHAp/PCL+cipro ir $312 \mathrm{~h}$, bet minimālais $-264 \mathrm{~h}$ (2.7. attēls). Manna-Vitnija tests uzrāda, ka starp CDHAp/PCL+cipro un CDHAp+cipro pret $P$. aeruginosa ir statistiski ticama atšķirība $(\mathrm{p}<0,001)$.

Kā rāda $P$. aeruginosa augšanas inhibīcijas dinamika, tad antibiotiskās vielas no $\mathrm{CDHAp/PCL+cipro} \mathrm{izdalās} \mathrm{pakāpeniski} \mathrm{un} \mathrm{pietiekami} \mathrm{lielā}$ daudzumā, lai 168 līdz 192 h ilgi inhibētu visas $P$. aeruginosa baktērijas. Pēc šīs laika atzīmes izdalīto antibiotisko vielu daudzums vairs nav pietiekams, lai nomāktu visas $P$. aeruginosa baktērijas, bet pēc 336 h antibakteriālās īpašības 
izzūd pavisam. CDHAp+cipro antibakteriālo īpašību zudums pret $P$. aeruginosa saskaņāa ar Manna-Vitnija testu pētījuma laika posmā no $24 \mathrm{~h}$ līdz $48 \mathrm{~h}$ ir statistiski ticams $(p<0,05)$. Šādas izmaiņas nenovēro CDHAp/PCL+cipro materiālam (statistiski ticami neatšķiras, $\mathrm{p}>0,05$ ).

Salīdzinot CDHAp/PCL+cipro spēju inhibēt $P$. aeruginosa ar S. epidermidis augšanu, redzams, ka CDHAp/PCL+cipro nomāc lielāko daļu S. epidermidis ilgāku laika periodu nekā $P$. aeruginosa. Kopējais CDHAp/PCL+cipro antibakteriālais laiks pret S. epidermidis ir 304,8 $\pm 11,59 \mathrm{~h}$, maksimālais antibakteriālais laiks - $312 \mathrm{~h}$, minimālais antibakteriālais laiks 288 h. Starp CDHAp/PCL+cipro un CDHAp+cipro pret S. epidermidis novēro statistiski ticamas $(\mathrm{p}<0,001)$ atšksirības antibakteriālajā laikā.

\subsection{IL-10 ekspresijas intensitāte in vivo}

Kompozītmateriāliem - HAp/PLLA+genta, HAp/PLLA+cipro, HAp+ genta un HAp+cipro, kas kontaminēti ar S. epidermidis, - neatkarīgi no izmeklējamo audu lokalizācijas attiecībā pret implantēto biomateriālu nenovēroja statistiski ticamas izmaiņas ( $\mathrm{p}>0,05$, Manna-Vitnija tests), salīdzinot ar kontroles grupu (2.1. tabula). Savukārt kompozītmateriāliem bez antibiotiskajām vielām (ciprofloksacīna vai gentamicīna), kas kontaminēti ar $S$. epidermidis baktēriju suspensiju, IL-10 intensitātes paaugstināšanos novēroja statistiski ticami ( $\mathrm{p}<0,05$, Manna-Vitnija tests) visos pētāmās grupas izmeklējamos audos, salīdzinot ar kontroles grupu. Lielākā IL-10 intensitāte tika noteikta audos, kuri tieši kontaktē ar implantēto HAp/PLLA kompozītmateriālu. Statistiski ticamas ( $\mathrm{p}>0,05$, Manna-Vitnija tests) izmaiņas nenovēroja IL-10 intensitātes līmenī starp audiem, kas ir tiešā kontaktā ar biomateriāliem, un audiem, kas ir tiešā kontakta ārējā zonā. Distancēti no implantētā HAp/PLLA atrodošajos audos novēroja statistiski ticamu $(\mathrm{p}<0,05)$ IL-10 intensitātes samazinājumu, salīizinot ar IL-10 intensitāti tiešā kontakta 
audos. Salīdzinot IL-10 intensitāti distancēti lokalizētajos audos ar kontroles grupas audiem, redzamas statistiski ticamas $(\mathrm{p}<0,05)$ atšşirības.

Kontaminējot HAp/PLLA+genta, HAp/PLLA+ciparo, HAp+genta un HAp+cipro ar P. aeruginosa baktēriju kultūru, neatkarīgi no izmeklējamo audu novietojuma ap biomateriālu netika novērotas statistiski ticamas atšķirības ( $p>0,05)$ IL-10 ekspresijā (2.2. tabula).

Manna-Vitnija tests parādīja statistiski ticamas $(\mathrm{p}<0,05)$ IL-10 līmeņa atšķirības starp kontroles grupas un pārējiem izmeklējamiem audiem HAp/PLLA implantācijas un $P$. aeruginosa kontaminācijas gadījumā.

Statistiski ticami $(\mathrm{p}<0,05)$ lielāka IL-10 intensitāte tika novērota tiešā kontakta audos - gan tieši kontaktējošos ar HAp/PLLA, gan tiešā kontakta arējā malā -, salīdzinot ar kontroles grupu, bet statistiski ticamas ( $\mathrm{p}>0,05)$ atšķirības starp abām (iekšējās un ārējās zonas) tiešā kontakta audu grupām netika atrastas. IL-10 intensitātes līmenis statistiski ticami $(p<0,05)$ samazinās distancēti izmeklētajos audos, bet joprojām saglabājas statistiski ticamas $(\mathrm{p}<0,05)$ atšķirīibas ar izmeklēto kontroles grupu (veseliem dzīvniekiem bez biomateriāla implantācijas).

2.1. tabula

\section{IL-10 līmenis pēc brūces kontaminācijas ar S. epidermidis (pg/ml)}

\begin{tabular}{|c|c|c|c|c|}
\hline $\begin{array}{c}\text { Biomateriāla } \\
\text { paraugs }\end{array}$ & $\begin{array}{c}\text { Tiešā } \\
\text { kontakta } \\
\text { iekšejāa } \\
\text { zona }\end{array}$ & $\begin{array}{c}\text { Tiešā } \\
\text { kontakta } \\
\text { arējā zona }\end{array}$ & Distancēti & $\begin{array}{c}\text { Kontroles grupa } \\
\text { (bez } \\
\text { implantācijas un } \\
\text { brūces } \\
\text { kontaminācijas) }\end{array}$ \\
\hline HAp/PLLA+cipro & $131 \pm 4,04$ & $131 \pm 7,00$ & $133 \pm 5,29$ & $133 \pm 7,63$ \\
\hline HAp+cipro & $137 \pm 2,00$ & $135 \pm 2,64$ & $139 \pm 1,00$ & $133 \pm 7,63$ \\
\hline HAp/PLLA+genta & $133 \pm 5,69$ & $134 \pm 6,03$ & $133 \pm 7,64$ & $133 \pm 7,63$ \\
\hline HAp+genta & $132 \pm 5,69$ & $135 \pm 6,56$ & $133 \pm 8,19$ & $133 \pm 7,63$ \\
\hline HAp/PLLA & $204 \pm 4,04$ & $194 \pm 2,04$ & $156 \pm 3,00$ & $133 \pm 7,63$ \\
\hline
\end{tabular}




\section{IL-10 līmenis pēc brūces kontaminācijas ar P. aeruginosa $(\mathrm{pg} / \mathrm{ml})$}

\begin{tabular}{|c|c|c|c|c|}
\hline $\begin{array}{c}\text { Biomateriāla } \\
\text { paraugs }\end{array}$ & $\begin{array}{c}\text { Tiešā } \\
\text { kontakta } \\
\text { iekšejā zona }\end{array}$ & $\begin{array}{c}\text { Tiešā } \\
\text { kontakta } \\
\text { arējā zona }\end{array}$ & Distancēti & $\begin{array}{c}\text { Kontroles grupa } \\
\text { (bez } \\
\text { implantācijas un } \\
\text { brūces } \\
\text { kontaminācijas) }\end{array}$ \\
\hline HAp/PLLA+cipro & $133 \pm 5,51$ & $132 \pm 3,79$ & $133 \pm 6,66$ & $133 \pm 7,63$ \\
\hline HAp+cipro & $135 \pm 6,03$ & $131 \pm 7,37$ & $133 \pm 6,11$ & $133 \pm 7,63$ \\
\hline HAp/PLLA+genta & $133 \pm 3,46$ & $131 \pm 6,00$ & $137 \pm 4,58$ & $133 \pm 7,63$ \\
\hline HAp+genta & $135 \pm 6,11$ & $132 \pm 4,04$ & $132 \pm 1,01$ & $133 \pm 7,63$ \\
\hline HAp/PLLA & $212 \pm 4,58$ & $206 \pm 2,64$ & $150 \pm 5,56$ & $133 \pm 7,63$ \\
\hline
\end{tabular}

\subsection{TNF-alfa ekspresijas intensitāte in vivo}

TNF-alfa TNF-alfa intensitātes līmenis izmeklējamos audos gan S. epidermidis (2.3. tabula), gan $P$. aeruginosa (2.4. tabula) kontaminācijas gadījumā neizmainās un netiek novērotas statistiski ticamas $(p>0,05)$ atšķirības ar kontroles grupu, ja tiek implantēti kompozītmateriāli ar antibiotiskajām vielām.

Intensīvāko TNF-alfa ekspresiju novēro tiešā kontaktā esošos audos ap HAp/PLLA, kas kontaminēts ar S. epidermidis vai $P$. aeruginosa. TNF-alfa ekspresija abu baktēriju kontaminācijas gadījumā ir statistiski ticami (p < 0,001) intensīvāka, salīdzinot ar kontroles grupu. Ja HAp/PLLA tiek kontaminēts ar $P$. aeruginosa, novēro visintensīvāko TNF-alfa ekspresiju tiešā kontakta audos. Pēc TNF-alfa intensitātes no HAp/PLLA distancēti novietotajos audos var spriest, ka iekaisuma zona samazinās, jo abu baktēriju kultūru gadījumā novēro statistiski ticamu $(\mathrm{p}<0,05)$ atšķirību TNF-alfa intensitātē starp tiešā kontakta audiem un distancēti novietotajiem audiem. Iespējams, ka iekaisuma zona ir lielāka, ņemot vērā, ka TNF-alfa intensitātes 
līmenis abu baktēriju kultūru gadījumos distancēti novietotajos audos ir statistiski ticami $(\mathrm{p}<0,05)$ lielāks nekā kontroles grupai.

2.3. tabula

TNF-alfa līmenis pēc brūces kontaminācijas ar S. epidermidis $(\mathrm{pg} / \mathrm{ml})$

\begin{tabular}{|c|c|c|c|c|}
\hline $\begin{array}{c}\text { Biomateriāla } \\
\text { paraugs }\end{array}$ & $\begin{array}{c}\text { Tiešā } \\
\text { kontakta } \\
\text { iekšējā } \\
\text { zona }\end{array}$ & $\begin{array}{c}\text { Tiešā } \\
\text { kontakta } \\
\text { arējā zona }\end{array}$ & Distancēti & $\begin{array}{c}\text { Kontroles grupa } \\
\text { (bez } \\
\text { implantācijas un } \\
\text { brūces } \\
\text { kontaminācijas) }\end{array}$ \\
\hline HAp/PLLA+cipro & $177 \pm 9,60$ & $176 \pm 10,5$ & $171 \pm 1,52$ & $177 \pm 7,63$ \\
\hline HAp+cipro & $174 \pm 8,38$ & $168 \pm 3,51$ & $166 \pm 4,04$ & $177 \pm 7,63$ \\
\hline HAp/PLLA+genta & $181 \pm 5,03$ & $179 \pm 2,08$ & $176 \pm 7,09$ & $177 \pm 7,63$ \\
\hline HAp+genta & $185 \pm 2,08$ & $182 \pm 1,53$ & $173 \pm 6,11$ & $177 \pm 7,63$ \\
\hline HAp/PLLA & $271 \pm 3,21$ & $268 \pm 3,78$ & $213 \pm 1,52$ & $177 \pm 7,63$ \\
\hline
\end{tabular}

2.4. tabula

TNF-alfa līmeṇi pēc brūces kontaminācijas ar $P$. aeruginosa $(\mathrm{pg} / \mathrm{ml})$

\begin{tabular}{|c|c|c|c|c|}
\hline $\begin{array}{c}\text { Biomateriāla } \\
\text { paraugs }\end{array}$ & $\begin{array}{c}\text { Tiešā } \\
\text { kontakta } \\
\text { iekšējāa } \\
\text { zona }\end{array}$ & $\begin{array}{c}\text { Tiešā } \\
\text { kontakta } \\
\text { arējā zona }\end{array}$ & Distancēti & $\begin{array}{c}\text { Kontroles grupa } \\
\text { (bez } \\
\text { implantācijas un } \\
\text { brūces } \\
\text { kontaminācijas) }\end{array}$ \\
\hline HAp/PLLA+cipro & $178 \pm 7,54$ & $174 \pm 7,21$ & $173 \pm 2,00$ & $177 \pm 7,63$ \\
\hline HAp+cipro & $180 \pm 5,13$ & $177 \pm 7,63$ & $173 \pm 5,77$ & $177 \pm 7,63$ \\
\hline HAp/PLLA+genta & $170 \pm 2,65$ & $168 \pm 2,52$ & $174 \pm 6,43$ & $177 \pm 7,63$ \\
\hline HAp+genta & $174 \pm$ & $170 \pm 12,86$ & $170 \pm 8,66$ & $177 \pm 7,63$ \\
\hline HAp/PLLA & $271 \pm 3,21$ & $268 \pm 3,78$ & $213 \pm 1,52$ & $177 \pm 7,63$ \\
\hline
\end{tabular}




\subsection{Beta-defensīna-2 ekspresijas intensitāte in vivo}

Intensīvākā beta-defensīna-2 ekspresija notiek audos, kas ir visciešākajā kontaktā ar S. epidermidis kontaminētu HAp/PLLA (2.5. tabula); salīdzinot ar kontroles grupas beta-defensīna-2 līmeni, novēroja statistiski ticamas izmaiṇas $(\mathrm{p}<0,05)$. Starp tiešā kontakta ārējo un iekšējo audu zonu nenovēroja statistiski ticamas izmaiņas $(\mathrm{p}>0,05)$. Statistiski ticamas $(\mathrm{p}<0,05)$ izmaiņas beta-defensīna-2 intensitātes līmen̄̄ novēro starp tiešā kontakta zonu un distancēti novietotajiem audiem HAp/PLLA implantācijas gadījumā, kas liecina par beta-defensīna-2 intensitātes samazinājumu. Beta-defensīna-2 līmeņa izmaiņas audos netika novērotas, implantējot kompozītmateriālu ar antibiotiskajām vielām.

Kontaminējot HAp/PLLA+cipro, HAp+cipro, HAp/PLLA+genta un HAp+genta ar $P$. aeruginosa, pēc 4 nedēlu implantācijas nenovēroja betadefensīna-2 līmeņa izmaiņas, salīdzinot ar kontroles grupu (2.6. tabula). Izmaiņas beta-defensīna-2 intensitātes līmenī novēroja audos pēc HAp/PLLA implantācijas un kontaminācijas ar P. aeruginosa.

Līdzīgi kā $S$. epidermidis kontaminācijas gadījumā, arī $P$. aeruginosa kontaminācijas gadījumā visintensīvāko beta-defensīna-2 ekspresiju novēroja tiešā kontakta audos ap HAp/PLLA.

Beta-defensīna-2 intensitātes līmenis statistiski ticami $(\mathrm{p}<0,05)$ samazinās distancēti atrodošajos audos, salīdzinot ar tiešā kontakta audu zonu, bet nav statistiski ticama $(p>0,05)$ atšķirība starp beta-defensīna-2 intensitātes līmeni distancēti novietotajos audos un kontroles grupu. 
Beta-defensīna-2 līmeṇi pēc brūces kontaminācijas ar $S$. epidermidis (pg/ml)

\begin{tabular}{|c|c|c|c|c|}
\hline $\begin{array}{c}\text { Biomateriāla } \\
\text { paraugs }\end{array}$ & $\begin{array}{c}\text { Tiešā } \\
\text { kontakta } \\
\text { iekšējā } \\
\text { zona } \\
\text { konējā zona }\end{array}$ & $\begin{array}{c}\text { Tiešā } \\
\text { kontakta }\end{array}$ & Distancēti & $\begin{array}{c}\text { Kontroles grupa } \\
\text { (bez } \\
\text { implantācijas un } \\
\text { brūces } \\
\text { kontaminācijas) }\end{array}$ \\
\hline HAp/PLLA+cipro & $326 \pm 4,04$ & $316 \pm 3,21$ & $319 \pm 6,55$ & $324 \pm 11,01$ \\
\hline HAp+cipro & $323 \pm 6,24$ & $319 \pm 1,00$ & $316 \pm 4,00$ & $324 \pm 11,01$ \\
\hline HAp/PLLA+genta & $325 \pm 2,52$ & $317 \pm 2,65$ & $321 \pm 3,21$ & $324 \pm 11,01$ \\
\hline HAp+genta & $319 \pm 3,21$ & $320 \pm 2,00$ & $317 \pm 4,58$ & $324 \pm 11,01$ \\
\hline HAp/PLLA & $395 \pm 4,35$ & $394 \pm 4,35$ & $339 \pm 3,50$ & $324 \pm 11,01$ \\
\hline
\end{tabular}

2.6. tabula

Beta-defensīna-2 līmeņi pēc brūces kontaminācijas ar $\boldsymbol{P}$. aeruginosa (pg/ml)

\begin{tabular}{|c|c|c|c|c|}
\hline $\begin{array}{c}\text { Biomateriāla } \\
\text { paraugs }\end{array}$ & $\begin{array}{c}\text { Tiešā } \\
\text { kontakta } \\
\text { iekšējā } \\
\text { zona } \\
\text { kon̄jā zona }\end{array}$ & $\begin{array}{c}\text { Tiešā } \\
\text { kontakta }\end{array}$ & Distancēti & $\begin{array}{c}\text { Kontroles grupa } \\
\text { (bez } \\
\text { implantācijas un } \\
\text { brūces } \\
\text { kontaminācijas) }\end{array}$ \\
\hline HAp/PLLA+cipro & $324 \pm 4,93$ & $312 \pm 1,00$ & $319 \pm 1,00$ & $324 \pm 11,01$ \\
\hline HAp+cipro & $323 \pm 1,12$ & $319 \pm 6,65$ & $315 \pm 1,00$ & $324 \pm 11,01$ \\
\hline HAp/PLLA+genta & $323 \pm 6,11$ & $317 \pm 2,65$ & $317 \pm 3,61$ & $324 \pm 11,01$ \\
\hline HAp+genta & $318 \pm 1,00$ & $319 \pm 3,51$ & $317 \pm 1,00$ & $324 \pm 11,01$ \\
\hline HAp/PLLA & $395 \pm 4,35$ & $394 \pm 4,35$ & $339 \pm 3,50$ & $324 \pm 11,01$ \\
\hline
\end{tabular}




\section{DISKUSIJA}

\subsection{Kompozītmateriālu efektivitāte in vitro}

Biomateriālu izmantošana medicīnā, lai aizvietotu orgāna vai tā daḷu funkcijas, kḷūst arvien plašāka, lai nodrošinātu pacientu dzīves kvalitāti un ilgumu (piemēram, mākslīgais sirds vārstulis).

Gandrīz visās medicīnas nozarēs tiek izmantoti biomedicīniskie implantāti diagnostisko manipulāciju vai terapijas nolūkos - intravenozie un urīnpūšla katetri, intubācijas aprīkojums, locītavu protēzes un cits biomedicīniskais aprīkojums. Taču, lietojot šos biomedicīskos implantātus, pastāv infekcijas attīstības risks (Huebsch et al., 2009).

Papildu infekcija, kas rodas blakus jau esošai saslimšanai, paildzina pacienta hospitalizācijas laiku, palielina ārstēšanas izmaksas un letalitātes risku. Biomateriālu saistītās infekcijas (BAI) attīstības risks visiem pacientiem nav vienāds; to nosaka vairāki faktori, kas saistīti ar pašu pacientu, implantanta veidu un operācijas apjomu. Gados vecākiem vai imūnsupresētiem pacientiem, pacientiem ar l̦aundabīgo audzēju vai ar ādas bojājumiem ir lielāks BAI risks, jo šo pacientu imūnās sistēmas darbības spējas pret BAI ierosinātājiem ir samazinātas (Laupland et al., 2006; Goldmann et al., 1993, Greco et al., 2015).

BAI risku nosaka operācijas apjoms un operācijas vietas sterilitāte. Ortopēdisko operāciju laikā brūces apjoms ir liels, brūce var kalpot par baktēriju ieejas vārtiem, kam seko BAI attīstība. Operāciju zāles gaisa mikroflora, pacienta ādas un gḷotādas mikroflora un personāla mikroflora ir infekcijas izraisošo baktēriju avots (Vinh et al., 2005).

Zobu implantātus un mutes dobumu operācijas notiek vidē, kurā ir atrodama viena no bagātākajām cilvēka normālajām mikroflorām. Lai arī šīs baktērijas pieder pie normālās cilvēka mikrofloras, tās vienlaicīgi ir 
oportūnistiskās baktērijas. Šādas ķirurğiskās manipulācijas dod iespēju baktērijām ierosināt BAI (Heydenrijk et al., 2002).

Atsevišķu BAI attīstības risks nav liels, taču letalitātes risks ir augsts. Letalitātes risks ir atkarīgs no pacienta veselības stāvokḷa, infekcijas lokalizācijas un plašuma. Urīnceļu infekcijas pēc urīnpūšlı katetrizācijas attīstās apmēram 30\% gadījumu, bet pacientu letalitāte šo infekciju dēl tiek vērtēta kā ļoti zema. Savukārt mākslīgo sirds vārstuḷu infekcijas attīstās 1-3\% gadījumu, bet pacientu letalitātes risks šo infekciju dēl ir vērtējams kā augsts (Darouiche et al., 2001, Wright et al., 2013).

Lai samazinātu BAI attīstības iespēju, slimnīcās pirms un pēc implantācijas operācijas tiek nozīmēta antibiotisko vielu terapija, kuras mērķis ir samazināt iespējamo oportūnisko baktēriju klātbūtni un iespēju ierosināt infekcijas, kā arī samazināt biomateriālu kontaminācijas risku operācijas laikā vai pēcoperācijas periodā (von Eiff et al., 2005).

Sistēmiskai antibiotisko vielu lietošanai ir vairāki trūkumi, salīdzinot ar lokālu antibiotisko vielu lietošanu. Viena no biežākajām problēmām ir disbakteriozes attīstība, kad tiek iznīcināta cilvēka normālā mikroflora kungǵa un zarnu traktā, mutes dobumā vai citās ķermeņa dạ̦ās. Disbakterioze var kalpot kā veicinošs faktors citu baktēriju ierosinātām infekcijām, piemēram, C. difficile ierosinātam pseidomembranozam kolītam (Mylonakis et al., 2001, Aldrete Sdel et al., 2015).

Lietojot antibiotiskās vielas sistēmiski, tās mazā koncentrācijā nonāk audos visā cilvēka organismā. Mazā antibiotisko vielu koncentrācija ir iemesls normālās mikrofloras baktēriju un infekciju ierosinātāju baktēriju rezistences attīstībai pret antibiotiskajām vielām. Hepatotoksicitāte, nefrotoksicitāte, ototoksicitāte un citas komplikācijas ir sistēmisku antibiotisko vielu lietošanas rezultāts. Sistēmiskai antibiotisko vielu lietošanai ir limitētas iespējas gadījumos, ja pacientam pēc antibiotisko vielu lietošanas ir blakusparādības - 
slikta dūša, vemšana, alerǵiskas reakcijas, izsitumi utt. (Cunha et al., 2001; Soothill et al., 2015).

Lokālai antibiotisko vielu lietošanai ir noteiktas priekšrocības, it sevišķi biomateriālu implantācijas operāciju gadījumā, kad antibiotiskās vielas tiek izdalītas no biomateriāla, kas ir ar tām piesūcinātas(Gottenbos et al., 2002; Pritchard et al., 2013).

Šajā darbā galvenais uzdevums bija izpētīt ar antibiotiskajām vielām un bionoārdamiem polimēriem piesūcināta hidrosiapatīta antibakteriālās îpašības in vitro un to biosaderību in vivo pētījumā pēc biomateriāla implantācijas un kontaminācijas ar baktēriju kultūrām, nosakot iekaisuma citokīnu IL-10, TNF- $\alpha$ un antibakteriālā peptīda $\beta$-defensīna-2 intensitāti apkārtējos audos ap implantēto biomateriālu. Šo biomateriālu iespējamais pielietojums ir kaulaudu reǵenerācijā pacientiem ar BAI risku.

Hospitālī iegūto infekciju ierosinātāji ir gan starp gramnegatīvām (E. coli, P. aeruginosa, K. pneumoniae), gan starp grampozitīvām baktērijām (S. aureus, S. epidermidis), un vairums no tām ir atrodamas ne tikai slimnīcas vidē, bet arī cilvēka normālajā mikroflorā. Retos gadījumos pētījumos tiek pārbaudīta biomateriālu pretsēnīšu darbība, un šim nolūkam tiek izvēlēts C. albicans vai kāds cits Candida ǵints pārstāvis, kuriem arī ir spēja ierosināt BAI. Daudzu autoru pētījumos ir norādes par plašo ierosinātāju daudzveidību. Viena pētījuma ietvaros tiek izmantotas vairākas baktēriju kultūras, lai pārbaudītu ar antibiotiskajām vielām piesūcinātu biomateriālu plašo antibakteriālo darbības spektru. Viena baktēriju kultūra pētījumos parasti tiek izvēlēta, ja baktērija ir biežākais kādas konkrētas saslimšanas ierosinātājs; tad tiek pārbaudīta potenciālā antibakteriālā darbība pret šo konkrēto ierosinātāju, lai novērstu saslimšanas attīstību, piemēram, S. aureus vai MRSA osteomielīta gadījumā. Grampozitīvo un gramnegatīvo baktēriju izmantošana viena pētījuma ietvaros tiek pamatota ar to, ka šīs baktērijas pārstāv cilvēka normālo 
mikrofloru, kas ierosina BAI (Peel et al., 2012; Vinh et al., 2005; von Eiff et al., 2005).

Lai izvērtētu pētījumā izmantotoLatvijā oriǵināli sintezēto biomateriālu antibakteriālās īpašības, tika izmantotas $S$. epidermidis un $P$. aeruginosa baktēriju kultūras. Šo baktēriju kultūru izvēle ir pamatota ar to, ka S. epidermidis ir viens no biežākajiem BAI, hospitālo infekciju un oportūnistisko infekciju ierosinātājiem. Augstā un plašā $P$. aeruginosa rezistence pret antibiotiskajām vielām, BAI un hospitālo infekciju ierosināšanas spēja pamato šīs baktēriju kultūras izmantošanu pētījumā.

Abām šīm baktēriju kultūrām ir raksturīgi vienlīdz aktīvi piesaistīties pie mākslīgo biomateriālu virsmām un veidot biofilmu. Tā kā biofilmu ierosināto infekciju ārstēšana ir sarežǵīta un bieži nesekmīga, pētījumā tika izmantoti kompozītmateriāli ar antibiotiskajām vielām, kuri nomāktu gan baktēriju adhēziju, gan baktēriju kolonizāciju.

Literatūras dati liecina, ka tiek izmantoti dažādi kompozītmateriāli ar dažādām antibiotiskajām vielām. Antibiotisko vielu izvēle galvenokārt balstās uz antibiotisko vielu spektru pret biežākajiem multirezistentajiem ierosinātājiem. Ciprofloksacīns tiek izmantots pētījumos, jo labi penetrē kaulaudos (Ahola et al., 2013). Atsevišķos pētījumos autori priekšroku dod vankomicīna izmantošanai, jo tas uzrāda izcilas antibakteriālās īpašības pret gramnegatīvajām, grampozitīvajām un arī rezistentajām baktērijām (Liana et al., 2013). Lokālai un kontrolētai antibiotisko vielu izdalei pētījumos tiek izmantots arī gentamicīns (Loca et al., 2011), ceftriaksons (Kundu et al., 2010), cefaleksīns (Li et al., 2011), amoksicilīns (Xu et al., 2008), doksicilīns (Feng et al., 2010) un citas.

Šì pētījuma ietvaros hidroksiapatīts tika piesūcināts ar ciprofloksacīnu vai gentamicīnu. Tā kā S. epidermidis un P. aeruginosa ir dažādas šūnas sienas uzbūve, tad ir jāizmanto antibiotiskās vielas ar atšķirīgu darbības mehānismu. Pēc sava darbības mehānisma ciprofloksacīns un gentamicīns ir atšķirīgas 
antibiotiskās vielas, bet to darbības spektrā ir gan $S$. epidermidis, gan P. aeruginosa.

Analizējot literatūras datus, nav atrodams identisks pētījums par kompozītmateriālu antibakteriālajām īpašībām. Atrodami pētījumi, kuri atspoguļo antibiotisko vielu izdali vai antibakteriālās īpašības līdzīgiem kompozītmateriāliem ar mūsu pētījumā iekḷautajiem biomaterilaiem (Leprêtre et al., 2009; Loca et al., 2015; Kankilic et al., 2014). Pêtījuma autoru antibiotisko vielu, baktēriju vai polimēru izvēle atšķiras. Taču mūsu pētījums un citu autoru pētījumus apvieno antibakteriālo īpašību salīdzināšana starp biomateriāliem ar bionoārdošos polimēru un bez polimēra. Ir atrodami daži pētījumi par IL-10, TNF- $\alpha$ un $\beta$-defensīna-2 ekspresiju apkārtējos audos pēc biomateriāla implantācijas (Gollwitzer et al., 2013; Ata-Ali et al., 2015; Reinis et al., 2011).

Mūsu pētījumā tika noskaidrots, ka HAp/PLLA+cipro antibakteriālās īpašības pret $S . \quad$ epidermidis saglabājas 278,4 $\pm 12,39 \mathrm{~h}$, bet CDHAp/PLLA+cipro - 213,6 \pm 13,26 h un CDHAp/PCL+cipro - 304,8 \pm 11,59 h . Biomateriāliem bez polimēra, bet ar antibiotiskajām vielām, antibakteriālais laiks pret $S$. epidermidis ir ievērojami īsāks nekā biomateriāliem ar polimēru, un ir 91,2 $\pm 10,11 \mathrm{~h} \mathrm{HAp+cipro} \mathrm{un} 72 \pm 16 \mathrm{~h}$ CDHAp+cipro.

Hidroksiapatītam, kas savienots ar ciklodekstrīna polimēru un ciprofloksacīnu, antibakteriālās īpašības pret $S$. aureus novēro līdz pat 240 h, bet paraugiem bez polimēra antibakteriālais laiks pret $S$. aureus ir tikai $144 \mathrm{~h}$. S. aureus izvēle šajā pêtījumā tiek pamatota ar to, ka šì baktērija var būt rezistenta pret antibiotiskajām vielām un pēc savas šūnas sienas uzbūves ir gandrīz vienāda ar daudziem grampozitīviem BAI ierosinātājiem (Leprêtre et al., 2009). Citā pētījumā sterila $S$. aureus zona ap hidroksiapatītu ar PLLA un vankomicīnu tiek novērota 432 h (Lian et al., 2013). 
Mūsu pētījumā izmantotajam HAp/PLLA+cipro antibakteriālās īpašības pret $P$. aeruginosa ilgst $249,6 \pm 13,39$ h, CDHAp/PLLA+cipro $-197 \pm 15,17$ h, bet CDHAp/PCL+cipro $-280,8 \pm 16,19$ h. Līdzīgi kā pret $S$. epidermidis, biomateriāli bez polimēra pret $P$. aeruginosa uzrāda mazāku antibakteriālo laiku. HAp+cipro atibakteriālais laiks pret $P$. aeruginosa ir 69,6 $\pm 7,58 \mathrm{~h}$, CDHAp+cipro $-60 \pm 12,64 \mathrm{~h}$.

Kompozītmateriāls $\mathrm{PCL} / \beta-\mathrm{TCP}+$ cipro antibakteriālo aktivitāti pret $P$. aeruginosa uzrāda jau uzreiz pēc $2 \mathrm{~h}$ inkubācijas. Citi autori (piemēram, Ahola et al., 2013) pierāda, ka antibiotiskās vielas izdalās ātri, pat 2 h laikā pēc inkubācijas sākuma. Šajā gadījumā tika izmantota antibiotiskā viela tetraciklīns, kas izdalījās no HAp/PCL kompozīta. Kopējo antibiotisko vielu izdales laiku no kompozītmateriāla ietekmē antibiotisko vielu daudzums izmantotajā kompozītmateriālā (Kim et al., 2004;). Ātrā antibiotisko vielu izdale no biomateriāla ir svarīga biofilmu veidošanās profilaksē uz tā virsmas. Pirmajās biofilmas veidošanās procesa stundās notiek baktēriju adhēzija pie biomateriāla, pēc kuras seko baktēriju proliferācija un biofilmas nobriešana. Antibiotiskajām vielām ātri izdaloties no biomateriāla, tiek inhibēta baktēriju adhēzija, tās nonāvējot. Baktēriju nespēja saistīties uz biomateriāla virsmas izslēdz biofilmas turpmākos veidošanās etapus.

Ortopēdisko infekciju ārstēšanā bez ciprofloksacīna tiek lietots arī vankomicīns. Š̄i antibiotiskā viela tiek lietota ārstēšanā gadījumos, ja ierosinātājs ir multirezistents pret antibiotiskajām vielām. Tāpēc vakcomicīnu izmanto biomateriālos ar ciklodekstrīna polimēru ilglaicīgai antibiotisko vielu izdalei. Šì kompozītmateriāla antibakteriālās īpašības pret $S$. aureus ilgst apmēram $144 \mathrm{~h}$, bet paraugiem bez ciklodekstrīna polimēra antibakteriālais ilgums ir tikai 96 h (Leprêtre et al., 2009).

Arī citi autori savos pētījumos ir pierādījuši bionoārdāmo polimēru ietekmi uz antibiotisko vielu izdales ātrumu un ilgumu. Piemēram, hidroksiapatīts ar PCL un vankomicīnu, salīdzinot ar hidrosiapatītu ar 
vankomicīnu bez PCL, vankomicīnu izdala ilgāk un pakāpeniski (Kim et al., 2005).

PLLA/ $\beta$-TCP ar vankomicīnu tiek rekomendēts izmantot pret MRSA, jo uzrāda labas antibakteriālās īpašības pret MRSA in vitro (Kankilic et al., 2011) un labas kaulaudu reǵenerācijas spējas pēc MRSA kontaminācijas in vivo (Kankilic et al., 2014), salīdzinot ar citiem biomateriālu paraugiem.

Modificētu kalcija fosfăta kaulu cementa biomateriālu ar PLLA un vankomicīnu spēja izdalīt antibiotiskās vielas ilgst līdz 43 dienām (Loca et al., 2015).

Pētījuma ietvaros nosakot hidroksiapatīta porainības līmeņa ietekmi uz antibakteriālo laiku, tika noskaidrots, ka zemākas porainības kompozītmateriālam $\downarrow$ HAp/PLLA+cipro antibakteriālais laiks pret $S$. epidermidis ir 151,2 $\pm 16,19$ h un pret $P$. aeruginosa $-117,6 \pm 13,62$ h. Zemākas porainības kompozītmateriālam bez bionoārdošā polimēra $\downarrow$ HAp+cipro antibakteriālais laiks pret S. epidermidis un P. aeruginosa ir tikai 52,8 $\pm 10,11 \mathrm{~h}$.

Citu autoru dati apstiprina kompozītmateriālu porainības ietekmi uz antibakteriālo laiku. Neatkarīgi no antibiotiskās vielas, kura tikusi izmantota pētījumā (ciprofloksacīns, gentamicīns, vankomicīns), mikroporainie hidroksiapatīti saturēja vairāk antibiotisko vielu nekā blīvākie hidroksiapatīti. Antibakteriālais laiks pret pētījumā izmantotajām E. coli, S. aureus un $P$. aeruginosa baktēriju kultūrām visos trīs antibiotisko vielu gadījumos bija garāks, ja tika izmantoti mikroporaini hidroksiapatīti, nevis blīvākie. Piesūcināmo antibiotisko vielu koncentrācija ir atkarīga no poru izmēra un to procentuālā daudzuma. Palielinot kompozītmateriāla porainību, palielinās iespējamais piesūcināto antibiotisko vielu daudzums, bet, samazinot porainību, samazinās iespējamais piesūcināto antibiotisko vielu daudzums (Chai et al., 2007; Schnieders et al., 2011). Ir svarīgi atrast optimālo līdzsvaru starp porainību un antibiotisko vielu daudzumu, lai biomateriāls nodrošinātu 
pietiekami ilgstošas antibakteriālās īpašības, jo, palielinot porainības līmeni, hidrosiapatītam samazinās mehāniskās izturības spējas.

Mūsu pētījumā kompozītmateriāli ar gentamicīnu saglabā tādu pašu antibakteriālā laika tendenci kā kompozītmateriāli, kas piesūcināti ar ciprofloksacīnu. Neatkarīgi no tā, kāda antibiotiskā viela tiek izmantota, kompozītiem ar polimēru ir ilgākas antibakteriālās īpašības nekā bez polimēra. HAp/PLLA+genta antibakteriālais laiks pret $S$. epidermidis ir 249,6 $\pm 16,78 \mathrm{~h}$, bet pret $P$. aeruginosa $-220,8 \pm 10,11$ h. Savukārt CDHAp/PCL+genta antibakteriālais laiks pret $S$. epidermidis ir $319,2 \pm 16,19$ h, pret $P$. aeruginosa $-264 \pm 16$ h. CDHAp/PLLA+genta antibakteriālais laiks pret S. epidermidis ir $249,6 \pm 16,78$ h, pret $P$. aeruginosa $-218,4 \pm 17,7$ h. Kompozītmateriāliem bez polimēra - HAp+genta, CDHAp+genta - antibakteriālais laiks pret $S$. epidermidis ir attiecīgi tikai $88,8 \pm 11,59 \mathrm{~h}$ un $67,2 \pm 10,11$, pret P. aeruginosa attiecīgi $-67,2 \pm 10,11$ h un $52,8 \pm 10,11$ h. Šādus kompozītmateriālus ar antibiotiskajām vielām un polimēru var izmantot gadījumos, kad pacientiem ar osteomielītu ir vajadzīga kaulu aizvietošanas operācija un ir jānodrošina antibakteriāla iedarbība uz ierosinātāju, lai neattīistītos BAI (Ahola et al., 2013). Osteomielìta gadījumā lokālai antibakteriālai terapijai ir priekšrocības, salīdzinot ar sistēmisku antibakteriālo terapiju, jo kaulaudi ir slikti apasiņoti un līdz ar to jau tā mazā antibiotisko vielu koncentrācija iekaisuma perēklī nonāk vēl mazāk.

In vitro pētījumā izmeklētās kompozītmateriālu grupas ar antibiotiskajām vielām un polimēru uzrāda ilgākas antibakteriālās īpašības, kas osteomielīta gadījumā būtu piemērotākas. Lai gan dati ir iegūti in vitro pētîjumā, pētījuma apstākḷi tiek nodrošināti līdzịgi, kādiem tiem būtu jābūt in vivo (tuvu cilvēka fiziologiskajiem apstākḷiem), līdz ar to iegūtos datus var attiecināt uz reāliem apstākḷiem in vivo.

Pētījumos, kur pret $S$. aureus ierosinātām saslimšanām tiek izmantots gentamicīns, redzams, ka hidrosiapatīta granulām ar gentamicīnu un keratīnu 
antibakteriālās īpašības pret S. aureus tiek novērotas 2904 h. Ir zināms, ka keratīnam piemīt stabilizējoša funkcija kompozītmateriālos, kas padara gentamicīna izdali no biomateriāla lēnāku (Belcarz et al., 2009).

Pētījuma laikā visi kompozītmateriāli ar PCL neatkarīgi no izmantotās antibiotiskās vielas vai baktēriju kultūras uzrāda ilgākas antibakteriālās īpašības nekā kompozītmateriāli ar PLLA. Tas ir skaidrojams ar to, ka PLLA un PCL ir dažāds bionoārdīšanās ātrums, respektīvi, PCL noārdās lēnāk nekā PLLA (Tokiwa et al., 2009). Labvēlīgos vides apstākḷlos PLLA degradējas 1-2 nedēḷu laikā, bet, ja vides apstākḷi nav labvēlīgi, biodegradācija var ilgt pat gadu. Savukārt PCL biodegradācija notiek aptuveni 2 gadu laikā, bet tas ir atkarīgs no PCL sākotnējās molekulārās masas implantā, līdz ar to biodegradācijas laiks var būt arī ̄̄sāks (Armentano et al., 2010; Gunatillake et al., 2003). Pateicoties savam ilgajam biodegradācijas laikam, PCL tiek plaši izmantots lokālas antibiotisko vielu izdales sistēmās, jo tādējādi antibakteriālās īpašības tiek nodrošinātas ilgāk (Woodruff et al., 2009). Lielāks antibiotisko vielu daudzums, iespējams, tika izdalīts no kompozītmateriāliem ar PLLA pirmajās pētījuma dienās. Šis daudzums bija pietiekams, lai pilnībā nomāktu baktēriju augšanu. PCL kompozītmateriālu izdalītais antibiotisko vielu daudzums nebija tik liels kā PLLA kompozītmateriāliem, taču, tas bija pietiekams, lai pilnībā nomāktu baktēriju augšanu pirmajās pētījuma dienās.

Vairāki autori bez PLLA un PCL savos pētījumos izmanto arī citus bionoārdošos polimērus, lai panāktu lokālu un vienmērīgu antibiotisko vielu izdalī̌sanos. Lielā polimēru daudzveidība un to daudzveidīgās īpašības autoriem ļauj izvēlēties vajadzīgo polimēru pēc nepieciešamības. Piemēram, PLGA ir bionoārdošs polimērs, ko izmanto kompozītmateriālos, lai izdalītu antibiotisko vielu - gentamicīnu (Schnieders et al., 2006; Liet al., 2011). PLGA ar gentamicīnu 432 h uzrāda antibakteriālās īpašības pret S. aureus (McLaren et al., 2014). 
Pateicoties ciprofloksacīna efektivitātei gan pret grampozitīvām, gan gramnegatīvām baktērijām, tas tiek izmantots daudzos pētījumos, lai nodrošinātu biomateriālu antibakteriālās īpašības un samazinātu BAI risku.

In vitro pētījumi liecina, ka ciprofloksacīns spēj labi darboties, adsorbēts uz biomateriāliem. Pētījumos (piemēram, Parwe et al., 2014) arī konstatēts, ka ar ciprofloksacīnu pārklātas PLLA nanošķiedras uzrāda antibakteriālo aktivitāti pret $S$. aureus jau pēc $24 \mathrm{~h}$ inkubācijas $37^{\circ} \mathrm{C}$ temperatūrā, un, lai pret $S$. aureus sasniegtu līdzīgu efektivitāti, tīra ciprofloksacīna koncentrācijai ir jābūt 8 reizes augstākai nekā tad, ja tas ir adsorbēts uz PLLA nanošķiedrām. Labākas antibakteriālās īpašības pret $E$. coli ir uzrādījušas PLLA nanošķiedras, kas pārklātas ar ciprofloksacīnu (Parwe et al., 2014).

Kohleārais implants ar ciprofloksacīnu 5 nedēlas saglabā antibakteriālās īpašības pret S. pneumoniae in vitro apstākḷ̆os $23{ }^{\circ} \mathrm{C}$ un $37{ }^{\circ} \mathrm{C}$ temperatūrā. Savukārt in vivo pētījumos ir konstatēts, ka kohleārais implants ar ciprofloksacīnu pasargā žurkas no $S$. pneumoniae meningīta, kas varētu būt iegūts hematogēnā cel̦ā. Kontaminējot šo implantu ar baktērijām tieši vidusausī, meningīts attīstījās pēc garāka inkubācijas perioda (Wei et al., 2006).

Polimerizētas nanosfēriskas kontaktlēcas ar ciprofloksacīnu līdz pat 96 stundām spēj inhibēt $S$. aureus un $P$. aeruginosa augšanu (Garhwal et al., 2012).

Ciklodekstrīna kombinācija ar ciprofloksacīnu paildzina biomateriālu antibakteriālās īpašības pret $S$. aureus, S. epidermidis un E. coli (Laurent et al., 2011).

Gentamicīna teicamās antibakteriālās īpašības pret gramnegatīvajām baktērijām ir iemesls, kāpēc š̄ antibiotiskā viela tiek plaši lietota biomateriālos.

Izmantojot gentamicīnu antibakteriālo biomaterālu izveidē, ir svarīgi noteikt tā termostabilitāti. Kaula rekonstrukcijā izmantojamo biomateriālu, kas pārklāts ar gentamicīnu, pirms kaulu rekonstrukcijas iespējams uzglabāt sasaldētā veidā. Saskaņā ar pētījumu (piemēram, Coraça-Huber et al., 2013) 
datiem, gentamicīna atbrīvošanās no protēzes $-20{ }^{\circ} \mathrm{C}$ un $-80{ }^{\circ} \mathrm{C}$ temperatūrā bija samērā līdzīga. Gentamicīna ş̧̧̄īumu pakļaujot $50{ }^{\circ} \mathrm{C}$ iedarbībai 30 minūtes, 77,91\% gentamicīna tiek degradēts, un tas liecina par zemu termostabilitāti un ierobežo tā izmantošanu. Gentamicīnu plaši lieto antibakteriālo biomateriālu izveidē, jo tam ir plašs darbības spektrs, turklāt cilvēka organisma temperatūra ir optimāla gentamicīna darbībai (Naveed et al., 2014).

Ar gentamicīnu klāts sintētiskais trūces tīklinšs in vitro pētījumos uzrāda augstas antibakteriālās īpašības pret $S$. aureus, tādējādi pasargājot pacientu no iespējamās postoperatīvās infekcijas (Wiegering et al., 2014). Tāpat pētījumos konstatēts, ka pēc asinsvadu implantu ievietošanas aptuveni $20 \%$ pacientu attīstās ar operāciju saistīta infekcija, taču asinsvadu kolagēna implants, kas klāts ar gentamicīnu, pēc operācijas nodrošina pilnīgu antibakteriālo aktivitāti. Pacientiem, kuriem izmantots implants ar gentamicīnu, novērots īsāks hospitalizācijas laiks (Costa Almeida et al., 2014).

Izteiktu antibakteriālo efektivitāti gentamicīns uzrāda arī ortopēdisko biomateriālu sastāvā. Ar gentamicīnu pārklātam kaula cementam ir izteikti ilgākas antibakteriālās īpašības pret $S$. aureus, MRSA, koagulāzes negatīvajiem stafilokokiem, E. coli, P. aeruginosa un Klebsiella spp. nekā cementam, kas klāts ar citām antibiotiskām vielām, piemēram, vankomicīnu, piperacilīnu vai imipenemu (Chang et al., 2013). Papēža kaula hroniska osteomielīta ārstēšana, izmantojot ar gentamicīnu piesūcinātu kalcija fosfăta cementu, ir sekmīga arī diabēta slimniekiem (Iwakura et al., 2014). Pacientiem, kuriem izmantoja gentamicīna polimetilmetakrilāta cementu kaula reǵenerācijai, novēroja gentamicīna izdalīšanos urīnā vidēji no 43 līdz 71 dienai (Webb et al., 2013). 


\subsection{Iekaisumu citokīnu ekspresija in vivo}

Pētījuma in vivo sadal̦ā tika noteikta iekaisuma citokīnu (TNF- $\alpha$ un IL-10) un antibakteriālo peptīdu ( $\beta$-defensīns-2) ekspresija apkārtējos audos pēc četru nedẹ̄lu HAp/PLLA+cipro, HAp/PLLA/+genta, HAp+cipro, HAp+genta un HAp/PLLA zemādas implantācijas un implanta kontaminācijas ar S. epidermidis vai $P$. aeruginosa.

Iekaisuma citokīnu produkcija ir organisma atbildes reakcija pret implantēto biomateriālu vai biomateriāla bakteriālo kontamināciju. Palielināta iekaisuma citokīnu daudzuma atrade var kalpot par diagnostisko kritēriju biomateriālu infekcijas gadījumā (Franz et al., 2011).

HAp/PLLA+cipro, HAp/PLLA/+genta, HAp+cipro un HAp+genta implantācijas un tai sekojošas bakteriālas kontaminācijas (neatkarīgi no tā, kāda baktēriju kultūra tika izmantota) apkārtējos audos ap biomateriālu netika novērotas TNF- $\alpha$, IL-10 un $\beta$-defensīna-2 ekspresijas izmaiņas. Neatkarīgi no tā, vai PLLA bija vai nebija biomateriālā, audos netika atrastas izmaiņas, salīdzinot ar kontroles grupu. Normālais iekaisuma citokīnu un antibakteriālo peptīdu daudzums liecina par to, ka pēc šo kompozītmateriālu implantācijas un kontaminācijas nav veidojies iekaisuma process, kas saistāms ar antibiotisko vielu izdali no biomateriāla un baktēriju iznīcināšanu. Baktēriju daudzums, kas tika izmantots in vivo pētījumā, bija pietiekami mazs, lai kompozītmateriāli ar un bez polimēra spētu baktērijas iznīcināt pilnībā, ko pierāda in vitro pētījuma sadaļa.

Pretēja situācija ir HAp/PLLA implantācijas un baktēriju kontaminācijas gadījumā. Pēc četru nedēlu implantācijas apkārtējos audos ekspresējas palielināts TNF- $\alpha$, IL-10 un $\beta$-defensīna-2 daudzums, kas skaidri liecina par iekaisuma procesu. N̦emot vērā, ka šis kompozītmateriāls nav piesūcināts ar antibiotiskām vielām, izmantotais baktēriju daudzums ir pietiekams, lai attīstītos iekaisuma process. 
Vairāki autori implantu infekciju gadījumā audos ap implantu ir novērojuši palielinātu IL-10 un TNF- $\alpha$ līmeni, salīdzinot ar implantiem bez infekcijas (Duarte et al., 2009). Šos rezultātus apstiprina citu autoru pētījumi, kuros pêtīti audi ap dentāliem implantiem iekaisuma gadījumā, salīdzinot ar veseliem audiem ap dentālo implantu (Ata-Ali et al., 2015).

Staphylocuccus spp. ierosināto locītavu implantu infekciju gadījumā locītavu somiņas šķidrumā ir atklāts paaugstināts TNF- $\alpha$ un $\beta$-defensīna-2 līmenis, kā arī paaugstināts vēl cita antibakteriālā peptīda - $\beta$-defensīna-3 lìmenis (Gollwitzer et al., 2013).

Intensīvāka TNF- $\alpha, \beta$-defensīna-2 un IL-10 produkcija audos ap biomateriālu ir novērota pēc kompozītmateriālu zemādas implantācijas un kontaminācijas ar P. aeruginosa vai S. epidermidis (Reinis et al., 2011). Biomateriāli, kas tikuši izmantoti pētījumā, ir bez antibiotiskajām vielām un kontaminēti ar mazāku baktēriju daudzumu nekā mūsu pētījumā, bet arī šāda baktēriju koncentrācija ir pietiekama, lai stimulētu iekaisuma citokīnu un antibakteriālo peptīdu produkciju ap biomateriāla audiem.

Neizmainīts TNF- $\alpha$ līmenis, salīdzinot ar kontroles grupu, tiek novērots gadījumos, kad lokāls vaskulārs implants ar vankomicīnu tiek kontaminēts ar MRSA. Šāds pats implants bez vankomicīna, bet kontaminēts ar baktēriju kultūru, izraisa palielinātu TNF- $\alpha$ produkciju (Gul et al., 2011). 


\section{SECINĀJUMI}

1. Biomateriāliem ar antibiotiskām vielām un ar bionoārdošo polimēru pārklājumu, piemīt izteiktas antibakteriālās īpašības; antibiotiskās vielas izdalās pakāpeniski un saglabājas ilgāk nekā biomateriāliem bez bionoārdošā polimēra pārklājuma, kuri antibiotiskās vielas izdala īslaicīgi.

2. Visu pētījumā iekḷauto biomateriālu (ar un bez polimēru pārklājuma) antibakteriālās darbības laiks pret $S$. epidermidis ir ilgāks nekā tādiem pašiem biomateriāliem pret $P$. aeruginosa; konstatēts, izmantojot divas dažādas antibakteriāāās testēšanas metodes.

3. Biomateriāliem ar antibiotiskajām vielām un PCL polimēru savienojumu antibakteriālās īpašības ir ilgstošākas nekā tādiem pašiem biomateriāliem ar PLLA (neatkarīgi no antibiotisko vielu veida vai baktēriju kultūras).

4. Ar antibiotiskajām vielām un ar polimēru savienotu zemas porainības biomateriālu antibakteriālais laiks pret $S$. epidermidis un $P$. aeruginosa ir īsāks nekā identiskiem biomateriāliem ar lielāku porainību.

5. Iekaisuma citokīnu un antibakteriālo peptīdu ekspresija audos ap biomateriālu ar antibiotiskajām vielām, kas kontaminēts ar S. epidermidis un $P$. aeruginosa, pēc implantācijas neatkarīgi no antibiotiskās vielas nemainās.

6. Palielināta iekaisuma citokīnu un antibakteriālo peptīdu izdales intensitāte ir novērojama audos ap kontaminētu, bet antibiotiskās vielas nesaturošu biomateriālu. 


\section{PUBLIKĀCIJAS UN PREZENTĀCIJAS PAR PẼTİJUMA TẼMU}

\section{Raksti starptautiski citējamās datubāzēs}

1. Skadins I., Kroica J., Salma I., Reinis A., Sokolova M., Rostoka D. The level of inflammatory cytokines and antimicrobial peptides after composite material implantation and contamination with bacterial culture. // Key Engineering Materials, 2017; 721: 245-250.

2. Narkevica I., Reinis A., Bugovecka L., Skadins I., Sansonetti E., Kroica J., Ozolins J. In vitro bioactivity and bacteriostasis effect of thermally treated and UV-light irradiated $\mathrm{TiO}_{2}$ ceramics. // Key Engineering Materials, 2016; 674: 121-126.

3. Brangule A., Gross K. A., Skadins I., Reinis A., Kroica J. Simultaneous identification of amorphous calcium phosphate and S.epidermidis bacteria by photoacoustic spectroscopy. // Key Engineering Materials, 2017; 720: 125-129.

4. Kroica J., Skadins I., Salma I., Reinis A., Sokolova M., Rostoka D., Berza N. Antibacterial efficiency of hydroxyapatite biomaterials with biodegrable polylactic acid and polycaprolactone polymers saturated with antibiotics. // Proceedings of the Latvian Academy of Sciences, Section B, 2016; 4(703): 20-30.

\section{Starptautiska mēroga uzstāšanās par publikācijas tēmu}

1. Skadins I., Reinis A., Kroica J. Analysis methods of antibacterial efficiency of retainers impregnated with antibiotics. // Symposium Bioceramics and cells for reinforcement of bone (18-20 October, 2012, Riga, Latvia).

2. Skadins I., Kroica J., Salma I., Reinis A., Sokolova M., Berza N. Antibacterial efficiency of hydroxyapatite biomaterials with biodegradable polylactic acid polymer, saturated with ciprofloxacin. // Scandinavian 
Society for Biomaterials - 7th Annual Meeting iNANO (Aarhus University, Aarhus, Denmark, 26-28 March, 2014).

3. Skadins I., Kroica J., Salma I., Reinis A., Sokolova M., Rostoka D., Berza N. Antibacterial efficiency of biomaterials with open porosity of $15 \%$ and total porosity of 20\%. // European Orthopaedic Research Society 22nd Annual Meeting (2-4 July, Nantes, France).

4. Skadins I., Kroica J., Salma I., Reinis A., Sokolova M., Rostoka D., Berza N. Biomaterials with biodegradable polymer and antibiotics efficiency tests in laboratories, practical use, advantages and disadvantages. // 12th Baltic Congress of Laboratory Medicine (Latvia, Riga, 18-20 September, 2014).

5. Skadins I., Kroica J., Salma I., Reinis A., Sokolova M., Rostoka D., Berza N. Antibacterial efficiency of hydroxyapatite biomaterials with biodegradable polycaprolactone polymer, saturated with ciprofloxacin. // 2nd Congress of Baltic Microbiologists (Tartu, Estonia, 16.10.201419.10.2014).

6. Skadins I., Kroica J., Salma I., Reinis A., Sokolova M., Rostoka D. Antibacterial effiency of biomaterials with biodegradable polymer and antibiotics. // Scandinavian Society for Biomaterials $-8^{\text {th }}$ conference (Sigulda, Latvia, 6-8 May, 2015).

\section{Starptautiska mēroga tēzes par pētījuma tēmu}

1. Skadins I., Kroica J., Salma I., Reinis A., Sokolova M., Berza N. Antibacterial efficiency of hydroxyapatite biomaterials with biodegradable polylactic acid polymer, saturated with ciprofloxacin. // Scandinavian Society for Biomaterials $-7^{\text {th }}$ Annual Meeting iNANO (Aarhus University, Aarhus, Denmark, 26-28 March 2014), O19. 
2. Skadins I., Kroica J., Salma I., Reinis A., Sokolova M., Rostoka D., Berza N. Antibacterial efficiency of hydroxyapatite biomaterials with biodegradable polylactic acid polymer, saturated with gentamicin. // $24^{\text {th }}$ European Congress of Clinical Microbiology and Infectious Diseases (in Barcelona, Spain, 10-13 May 2014), p. 016.

3. Skadins I., Kroica J., Salma I., Reinis A., Sokolova M., Rostoka D., Berza N. Antibacterial efficiency of biomaterials with open porosity of $15 \%$ and total porosity of 20\%. // European Orthopaedic Research Society $22^{\text {nd }}$ Annual Meeting (2-4 July, Nantes, France), O2.3.

4. Skadins I., Kroica J., Salma I., Reinis A., Sokolova M., Rostoka D., Berza N. Biomaterial antibacterial efficiency with reduced level of porosity. // European Orthopaedic Research Society $22^{\text {nd }}$ Annual Meeting (2-4 July, Nantes, France), p. 7.1.

5. Skadins I., J Kroica J., Salma I., Reinis A., Sokolova M., Rostoka D., Berza N. Antibacterial efficiency of hydroxyapatite biomaterials with biodegradable polycaprolactone polymer, saturated with gentamicin. // $12^{\text {th }}$ Baltic Congress of Laboratory Medicine (Latvia, Riga, 18-20 September, 2014), p. 42.

6. Skadins I., J Kroica J., Salma I., Reinis A., Sokolova M., Rostoka D., Berza N. Biomaterials with biodegradable polymer and antibiotics efficiency tests in laboratories, practical use, advantages and disadvantages. // $12^{\text {th }}$ Baltic Congress of Laboratory Medicine (Latvia, Riga, 18-20 September, 2014), p. 41.

7. Skadins I., J Kroica J., Salma I., Reinis A., Sokolova M., Rostoka D., Berza N. Antibacterial efficiency of hydroxyapatite biomaterials with biodegradable polycaprolactone polymer, saturated with ciprofloxacin. $/ / 2^{\text {nd }}$ Congress of Baltic Microbiologists (Tartu, Estonia, 16.10.201419.10.2014), p. 54. 
8. Skadins I., J Kroica J., Salma I., Reinis A., Sokolova M., Rostoka D. Antibacterial effiency of biomaterials with biodegradable polymer and antibiotics. // Scandinavian Society for Biomaterials $-8^{\text {th }}$ conference (Sigulda, Latvia, 6-8 May, 2015), p. 49.

\section{Latvijas mēroga uzstāšanās par promocijas darba pētījuma tēmu}

1. Skadins I., J Kroica J., Salma I., Reinis A., Sokolova M., Rostoka D., Berza N. Hidroksiapatīta-polipienskābes-ciprofloksacīna biomateriālu ar vidējo atvērto porainību $15 \%$ antibakteriālās efektivitātes noteikšana, izmantojot Kirby-Bauer difūzijas metodi. // RSU Zinātniskā konference (2014. gada 10.-11. aprīlis).

\section{Latvijas mēroga tēzes par pētījuma tēmu}

2. Skadins I., J Kroica J., Salma I., Reinis A., Sokolova M., Rostoka D., Berza N. Biomateriālu efektivitāte pret Ps. aeruginosa un S. epidermidis. // RSU Zinātniskā konference: Tēzes (2014. gada 10.-11. aprīlis). Rīga: RSU, 2014, 337. 1pp.

3. Skadins I., J Kroica J., Salma I., Reinis A., Sokolova M., Rostoka D., Berza N. Biomateriālu antibakteriālās efektivitātes noteikšana. RSU Zinātniskā konference: Tēzes (2014. gada 10.-11. aprīlis). Rīga: RSU, 2014, 335. 1pp.

4. Skadins I., J Kroica J., Salma I., Reinis A., Sokolova M., Rostoka D., Berza N. Hidroksiapatīta-polipienskābes-ciprofloksacīna biomateriālu ar vidējo atvērto porainību $15 \%$ antibakteriālās efektivitātes noteikšana, izmantojot Kirby-Bauer difūzijas metodi. RSU Zinātniskā konference: Tēzes (2014. gada 10.-11. aprīlis). Rīga: RSU, 2014, 334. lpp.

5. Skadins I., J Kroica J., Salma I., Reinis A., Sokolova M., Rostoka D., Berza N. Hidroksiapatīta-polipienskābes-ciprofloksacīna biomateriālu ar 
vidējo porainību $15 \%$ antibakteriālā efektivitāte in vitro. RSU Zinātniskā konference: Tēzes (2014. gada 10.-11. aprīlis). Rīga: RSU, 2014, 336. lpp.

6. Skadins I., J Kroica J., Salma I., Reinis A., Sokolova M., Rostoka D., Berza N., Brakovska P., Jaunzeme A., Pētersons K., Veckalns I., Pudule S. Biomateriālu antibakteriālās efektivitātes noteikšanas metodes ietekme uz antibakteriālo ilgumu. RSU Zinātniskā konference: Tēzes (2015. gada 26.-27. marts). Rīga: RSU, 2015, 307. lpp.

7. Skadins I., J Kroica J., Salma I., Reinis A., Sokolova M., Rostoka D., Berza N., Brakovska P., Jaunzeme A., Pētersons K., Veckalns I., Pudule S. Fiziologiskās vides ietekme uz biomateriāliem ar biodegradējamu polipienskābes polimēru. RSU Zinātniskā konference: Tēzes (2015. gada 26.-27. marts). Rīga: RSU, 2015, 306. lpp. 


\section{IZMANTOTĀ LITERATŪRA}

1. Ahola N., Männistö N., Veiranto M., Karp M., Rich J., Efimov A., et al. An in vitro study of composites of poly(L-lactide-co- $\varepsilon$-caprolactone), $\beta$-tricalcium phosphate and ciprofloxacin intended for local treatment of osteomyelitis // Biomatter, 2013; 3(2): e23162.

2. Aldrete Sdel M., Magee M. J., Friedman-Moraco R. J., Chan A. W., Banks G. G., Burd E. M., Kraft C. S. Characteristics and antibiotic use associated with shortterm risk of Clostridium difficile ilnfection among hospitalized patients // Am J Clin Pathol, 2015; 143(6): 895-900.

3. Ata-Ali J., Flichy-Fernández J. A., Alegre-Domingo T., Ata-Ali F., Palacio J., Peñarrocha-Diago M. Clinical, microbiological, and immunological aspects of healthy versus peri-implantitis tissue in full arch reconstruction patients: a prospective cross-sectional study // BMC Oral Health, 2015; 15: 4.

4. Bauer A. W., Bauer A. W., Kirby W. M. M., Sherris J. C., Turck M. Antibiotic susceptibility testing by a standardized single disk method // Am J Clin Pathol, 1966; 36: 493-496.

5. Belcarz A., Belcarz A., Ginalska G., Zalewska J., Rzeski W., Slósarczyk A., Kowalczuk D., et al. Covalent coating of hydroxyapatite by keratin stabilizes gentamicin release // J Biomed Mater Res B Appl Biomater, 2009; 89(1): 102113.

6. Campoccia D., Montanaro L., Speziale P., Arciola C. R. Antibiotic-loaded biomaterials and the risks for the spread of antibiotic resistance following their prophylactic and therapeutic clinical use // Biomaterials, 2010; 31(25): 63636377.

7. Chai F., Hornez J. C., Blanchemain N., Neut C., Descamps M., Hildebrand H. F. Antibacterial activation of hydroxyapatite (HA) with controlled porosity by different antibiotics // Biomol Eng, 2007 Nov; 24(5): 510-514.

8. Chang Y., Tai C. L., Hsieh P. H., Ueng S. W. Gentamicin in bone cement: a potentially more effective prophylactic measure of infectionin joint arthroplasty // Bone Joint Res, 2013; 2(10): 220-226.

9. Coraça-Huber D. C., Hausdorfer J., Fille M., Nogler M. Effect of storage temperature on gentamicin release from antibiotic-coated bone chips // Cell Tissue Bank, 2013; 14(3): 395-400.

10. Costa Almeida C. E., Reis L., Carvalho L., Costa Almeida C. M. Collagen implant with gentamicin sulphate reduces surgical site infection in vascular surgery: a prospective cohort study // Int J Surg, 2014; 12(10): 1100-1104.

11. Cunha B. A. Antibiotic side effects // Med Clin North Am, 2001; 85(1): 149-185.

12. Darouiche R. O. Device-associated infections: a macroproblem that starts with microadherence // Clin Infect Dis, 2001; 33(9): 1567-1572.

13. Duarte P. M., de Mendonça A. C., Máximo M. B., Santos V. R., Bastos M. F., Nociti Júnior F. H. Differential cytokine expressions affect the severity of periimplant disease // Clin Oral Implants Res, 2009; 20(5): 514-520. 
14. Feng K., Feng K., Sun H., Bradley M. A., Dupler E. J., Giannobile W. V., Ma P. X. Novel antibacterial nanofibrous PLLA scaffolds // J Control Release, 2010; 146(3): 363-369.

15. Franz S., Rammelt S., Scharnweber D., Simon J. C. Immune responses to implants - a review of the implications for the design of immunomodulatory biomaterials // Biomaterials, 2011; 32(28): 6692-6709.

16. Garhwal R., Shady S. F., Ellis E. J., Ellis J. Y., Leahy C. D., McCarthy S. P., et al. Sustained ocular delivery of Ciprofloxacin using nanospheres and conventional contact lens materials // Invest Ophthalmol Vis Sci, 2012; 53(3): 1341-1352.

17. Goldmann D. A., Pier G. B. Pathogenesis of infections related to intravascular catheterization // Clin Microbiol Rev, 1993; 6(2): 176-192.

18. Gollwitzer H., Dombrowski Y., Prodinger P. M., Peric M., Summer B., Hapfelmeier A., et al. Antimicrobial peptides and proinflammatory cytokines in periprosthetic joint infection // J Bone Joint Surg Am, 2013; 95(7): 644-651.

19. Gottenbos B., Busscher H. J., Van Der Mei H. C., Nieuwenhuis P. Pathogenesis and prevention of biomaterial centered infections // J Mater Sci Mater Med, 2002; 13(8): 717-722.

20. Greco G., Shi W., Michler R. E., Meltzer D. O., Ailawadi G., Hohmann S. F., Thourani V. H., Argenziano M., Alexander J. H., Sankovic K., Gupta L., Blackstone E. H., Acker M. A., Russo M. J., Lee A., Burks S. G., Gelijns A. C., Bagiella E., Moskowitz A. J., Gardner T. J. Costs associated with health careassociated infections in cardiac surgery // J Am Coll Cardiol, 2015; 65(1): 15-23.

21. Gul M., Yasim A., Aral M. The levels of cytokines in rats following the use of prophylactic agents in vascular graft infection // Bratisl Lek Listy, 2010; 111(6): 316-320.

22. Heydenrijk K., Meijer H. J., van der Reijden W. A., Raghoebar G. M., Vissink A., Stegenga B. Microbiota around root-form endosseous implants: a review of the literature // Int J Oral Maxillofac Implants, 2002; 17(6): 829-838.

23. Huebsch N., Mooney D. J. Inspiration and application in the evolution of biomaterials // Nature, 2009; 462(7272): 426-432.

24. Iwakura T., Lee S. Y., Niikura T., Miwa M., Sakai Y., Nishida K. et al. Gentamycin-impregnated calcium phosphate cement for calcaneal osteomyelitis: a case report // J Orthop Surg (Hong Kong). 2014; 22(3): 437-439.

25. Kankilic B., Bayramli E., Kilic E., Dağdeviren S., Korkusuz F. Vancomycin Containing PLLA/ $\beta$-TCP Controls MRSA In Vitro // Clin Orthop Relat Res, 2011; 469(11): 3222-3228.

26. Kankilic B., Bilgic E., Korkusuz P., Korkusuz F. Vancomycin containing PLLA/ $\beta$-TCP controls experimental osteomyelitis in vivo // J Orthop Surg Res, 2014; 19; 9:114.

27. Kim H. W., Knowles J. C., Kim H. E. Development of Hydroxyapatite Bone Scaffold for Controlled Drug Release via Poly( $\varepsilon$-caprolactone) and Hydroxyapatite Hybrid Coatings // J Biomed Mater Res B Appl Biomater, 2004; 70(2): 240-249. 
28. Kim H. W., Knowles J. C., Kim H. E. Hydroxyapatite porous scaffold engineered with biological polymer hybrid coating for antibiotic Vancomycin release // J Mater Sci Mater Med, 2005; 16(3): 189-195.

29. Kundu B., Soundrapandian C., Nandi S. K., Mukherjee P., Dandapat N., Roy S. Development of new localized drug delivery system based on ceftriaxonesulbactam composite drug impregnated porous hydroxyapatite: a systematic approach for in vitro and in vivo animal trial // Pharm Res, 2010; 27(8): 16591676.

30. Laupland K. B., Lee H., Gregson D. B., Manns B. J. Cost of intensive care unitacquired bloodstream infections // J Hosp Infect, 2006; 63(2): 124-132.

31. Laurent T., Kacem I., Blanchemain N., Cazaux F., Neut C., Hildebrand H. F., et al. Cyclodextrin and maltodextrin finishing of a polypropylene abdominal wall implant for the prolonged delivery of ciprofloxacin // Acta Biomater, 2011; 7(8): 3141-3149.

32. Leprêtre S., Chai F., Hornez J. C., Vermet G., Neut C., Descamps M., et al. Prolonged local antibiotics delivery from hydroxyapatite functionalised with cyclodextrin polymers // Biomaterials, 2009; 30(30): 6086-6093.

33. Li Z., Kong W., Li X., Xu C., He Y., Gao J. Antibiotic-containing biodegradable bead clusters with porous PLGA coating as controllable drug-releasing bone fillers // J Biomater Sci Polym Ed, 2011; 22(13): 1713-1731.

34. Lian X., Liuc H., Wanga X., Xua S., Cuia F., Bai X. Antibacterial and biocompatible properties of vancomycin-loaded nanohydroxyapatite/collagen/poly (lactic acid) bone substitute // Progress in Natural Science: Materials International, 2013; 23(6): 549-556.

35. Loca D., Locs J., Salma K., Gulbis J., Salma I., Berzina-Cimdina L. Porous Hydroxyapatite bioceramic scaffolds for drug delivery and bone regeneration // Mater. Sci. Eng., 2011; 18: 192019.

36. Loca D., Sokolova M., Locs J., Smirnova A., Irbe A. Calcium phosphate bone cements for local vancomycin delivery // Materials Science and Engineering: C, 2015; 49: 106-113.

37. Locs J., Zalite V., Berzina-Cimdina L., Sokolova M. Ammonium hydrogen carbonate provided viscous slurry foaming - a novel technology for the preparation of porous ceramics // J Eur Ceram Soc, 2013; 33: 3437-3443.

38. Mann H. B., Whitney D. R. On a Test of whether one of two random variables is stochastically larger than the other // Ann Math Statist, 1947; 18(1): 50-60.

39. McLaren J. S., White L. J., Cox H. C., Ashraf W., Rahman C.V., Blunn G. W., et al. A biodegradable antibiotic-impregnated scaffold to prevent osteomyelitis in a contaminated in vivo bone defect model // Eur Cell Mater, 2014; 27: 332-349.

40. Mylonakis E., Ryan E. T., Calderwood S. B. Clostridium difficile-associated diarrhea: a review // Arch Intern Med, 2001; 161(4): 525-533.

41. Naveed S., Waheed N., Nazeer S., Qamar F. Degradation study of gentamicin by UV spectroscopy // American Journal of Chemistry and Applications, 2014; 1(4): 36-39. 
42. Parwe S. P., Chaudhari P. N., Mohite K. K., Selukar B. S., Nande S. S., Garnaik B. Synthesis of ciprofloxacin-conjugated poly (L-lactic acid) polymer for nanofiber fabrication and antibacterial evaluation // Int J Nanomedicine, 2014; 9: 1463-1477.

43. Peel T. N., Cheng A. C., Buising K. L., Choong P. F. Microbiological aetiology, epidemiology, and clinical profile of prosthetic joint infections: are current antibiotic prophylaxis guidelines effective? // Antimicrob Agents Chemother, 2012; 56(5): 2386-2391.

44. Pritchard E. M., Valentin T., Panilaitis B., Omenetto F., Kaplan D. L. Antibioticreleasing silk biomaterials for infection prevention and treatment // Adv Funct Mater, 2013; 23(7): 854-861.

45. Reinis A., Pilmane M., Stunda A., Vētra J., Kroiča J., Rostoka D., et al. An in vitro and in vivo study on the intensity of adhesion and colonization by Staphylococcus epidermidis and Pseudomonas aeruginosa on originally synthesized biomaterials with different chemical composition and modified surfaces and their effect on expression of TNF- $\alpha, \beta$-defensin- 2 and IL-10 in tissues // Medicina (Kaunas), 2011; 47(10): 560-565.

46. Schnieders J., Gbureck U., Thull R., Kissel T. Controlled release of gentamicin from calcium phosphate-poly(lactic acid-co-glycolic acid) composite bone cement // Biomaterials, 2006; 27(23): 4239-4249.

47. Schnieders J., Gbureck U., Vorndran E., Schossig M., Kissel T. The effect of porosity on drug release kinetics from vancomycin microsphere/calcium phosphate cement composites // J Biomed Mater Res B Appl Biomater, 2011; 99(2): 391-398.

48. Sokolova M., Putniņš A., Kreicbergs I., Ločs J. Scale-up of wet precipitation calcium phosphate synthesis // Key Engineering Materials, 2014; 604: 216-219.

49. Soothill G., Hu Y., Coates A. Can we prevent antimicrobial resistance by using antimicrobials better? // Crit Rev Ther Drug Carrier Syst, 2015; 32(1): 1-59.

50. The European Committee on Antimicrobial Susceptibility Testing - EUCAST. Disk Diffusion Method for antimicrobial susceptibility testing, Manual ver. 5.0 //http://www.eucast.org/fileadmin/src/media/PDFs/EUCAST_files/Disk_test_docu ments/Manual_v_5.0_EUCAST_Disk_Test.pdf (sk. 04.02.2015.).

51. Tokiwa Y., Calabia B. P., Ugwu C. U., Aiba S. Biodegradability of plastics // Int J Mol Sci, 2009; 10(9): 3722-3742.

52. van de Belt H., Neut D., Schenk W., van Horn J. R., van der Mei H. C., Busscher H. J. Infection of orthopedic implants and the use of antibiotic-loaded bone cements. A review // Acta Orthop Scand, 2001; 72(6): 557-571.

53. Vinh D. C., Embil J. M. Device-related infections: a review // J Long Term Eff Med Implants, 2005; 15(5): 467-488.

54. von Eiff C., Jansen B., Kohnen W., Becker K. Infections associated with medical devices: pathogenesis, management and prophylaxis // Drugs, 2005; 65(2): 179_ 214. 
55. Webb J. C., Gbejuade H., Lovering A., Spencer R. Characterisation of in vivo release of gentamicin from polymethyl methacrylate cement using a novel method // Int Orthop, 2013; 37(10): 2031-2036.

56. Wei B. P. C., Robins-Browne R. M., Shepherd R. K., Azzopardi K., Clark G. M., O'Leary S. J. Protective effects of local administration of ciprofloxacin on the risk of pneumococcal meningitis following cochlear implantation // Laryngoscope, 2006; 116(12): 2138-2144.

57. Wiegering A., Sinha B., Spor L., Klinge U., Steger U., Germer C. T., et al. Gentamicin for prevention of intraoperative mesh contamination: demonstration of high bactericide effect (in vitro) and low systemic bioavailability (in vivo) // Hernia, 2014; 18(5): 691-700.

58. Wright J., Paauw D. S. Complications of antibiotic therapy // Med Clin North Am, 2013, 97(4): 667-679.

59. Xu Q., Czernuszka J. T. Controlled release of amoxicillin from hydroxyapatitecoated poly(lactic-co-glycolic acid) microspheres // J Control Release, 2008; 127(2): 146-1453. 